\title{
Characterization of Stem and Progenitor Cells in the Dental Pulp of Erupted and Unerupted Murine Molars
}

\author{
Anamaria Balic \\ University of Connecticut School of Medicine and Dentistry \\ Hector L. Aguila \\ University of Connecticut School of Medicine and Dentistry \\ Melissa J. Caimano \\ University of Connecticut School of Medicine and Dentistry \\ Victor P. Francone \\ University of Connecticut School of Medicine and Dentistry \\ Mina Mina \\ University of Connecticut School of Medicine and Dentistry
}

Follow this and additional works at: https://opencommons.uconn.edu/uchcres_articles Part of the Dentistry Commons

\section{Recommended Citation}

Balic, Anamaria; Aguila, Hector L.; Caimano, Melissa J.; Francone, Victor P.; and Mina, Mina, "Characterization of Stem and Progenitor Cells in the Dental Pulp of Erupted and Unerupted Murine Molars" (2010). UCHC Articles - Research. 34.

https://opencommons.uconn.edu/uchcres_articles/34 


\title{
Characterization of stem and progenitor cells in the dental pulp of erupted and unerupted murine molars
}

\author{
Anamaria Balic ${ }^{1}$, H. Leonardo Aguila ${ }^{2}$, Melissa J. Caimano ${ }^{3}$, Victor P. Francone ${ }^{4}$, and Mina \\ Mina $^{1}$ \\ ${ }^{1}$ Department of Craniofacial Sciences, School of Dental Medicine, University of Connecticut Health \\ Center, Farmington, CT. \\ ${ }^{2}$ Department of Immunology, School of Medicine, University of Connecticut Health Center, \\ Farmington, CT. \\ ${ }^{3}$ Department of Medicine, School of Medicine, University of Connecticut Health Center, Farmington, \\ CT. \\ ${ }^{4}$ Department of Neuroscience, School of Medicine, University of Connecticut Health Center, \\ Farmington, CT.
}

\begin{abstract}
In the past few years there have been significant advances in the identification of putative stem cells also referred to as "mesenchymal stem cells" (MSC) in dental tissues including the dental pulp. It is thought that MSC in dental pulp share certain similarities with MSC isolated from other tissues. However, cells in dental pulp are still poorly characterized. This study focused on the characterization of progenitor and stem cells in dental pulps of erupted and unerupted mice molars. Our study showed that dental pulps from unerupted molars contain a significant number of cells expressing CD90+/ CD45-, CD117+/CD45-, Sca-1+/CD45- and little if any CD45+ cells. Our in vitro functional studies showed that dental pulp cells from unerupted molars displayed extensive osteo-dentinogenic potential but were unable to differentiate into chondrocytes and adipocytes. Dental pulp from erupted molars displayed a reduced number of cells, contained higher percentage of CD45+ and lower percentage of cells expressing CD90+/CD45-, CD117+/CD45- as compared to unerupted molars. In vitro functional assays demonstrated the ability of a small fraction of cells to differentiate into odontoblasts, osteoblasts, adipocytes and chondrocytes. There was a significant reduction in the osteo-dentinogenic potential of the pulp cells derived from erupted molars compared to unerupted molars. Furthermore, the adipogenic and chondrogenic differentiation of pulp cells from erupted molars was dependent on a long induction period and infrequent. Based on these findings we propose that the dental pulp of the erupted molars contain a small population of multipotent cells, whereas the dental pulp of the unerupted molars does not contain multipotent cells but is enriched in osteodentinogenic progenitors engaged in the formation of coronal and radicular odontoblasts.
\end{abstract}

\section{(C) 2009 Elsevier Inc. All rights reserved.}

Address correspondence to: Mina Mina Division of Pediatric Dentistry Department of Craniofacial Sciences School of Dental Medicine University of Connecticut Health Center, Farmington, CT 06030 Telephone: (860) 679-4081 Fax: (860) 679-4078 Mina@ nso1.uchc.edu.

Publisher's Disclaimer: This is a PDF file of an unedited manuscript that has been accepted for publication. As a service to our customers we are providing this early version of the manuscript. The manuscript will undergo copyediting, typesetting, and review of the resulting proof before it is published in its final citable form. Please note that during the production process errors may be discovered which could affect the content, and all legal disclaimers that apply to the journal pertain. 


\section{Keywords}

Dental pulp; Dentin; Odontoblasts; progenitors; Bone

\section{Introduction}

Odontoblasts are exclusively dentin-producing cells morphologically and functionally distinct from osteoblasts secreting bone matrix. These highly specialized tall columnar cells are located at the periphery of the dental pulp and differentiate from neural crest-derived dental papilla cells at the late bell stage of tooth development [1]. The differentiation of dental papilla into odontoblasts is dependent on signals and growth factors derived from the inner dental epithelium and basement membrane [1].

After differentiation, odontoblasts secrete unmineralized predentin, a type I collagen-rich matrix considered to be similar to the osteoid in the bone [1,2]. Predentin mineralizes at the mineralization front to form dentin [1,2]. The mineralization of dentin is initiated and controlled by deposition of hydroxyapatite crystals and non-collagenous proteins (NCP) secreted by the odontoblasts [2-4]. Dentin phosphoprotein (DPP) and dentin sialoprotein (DSP) are specific cleavage products of a single gene named dentin sialophosphoprotein $(D S P P)$ with roles in dentin formation and mineralization [5-7]. Expression of DSPP and DSP has been used as a marker to distinguish differentiated odontoblasts from undifferentiated progenitors and from osteoblasts [8-10].

Dentin secreted by odontoblasts until the completion of root formation is defined as primary dentin. Following primary dentinogenesis, odontoblasts remain functional and secrete secondary dentin laid down after the complete eruption of the tooth into occlusion $[3,4]$. Secondary dentin is secreted throughout life at a much slower rate than primary dentin and results in a decrease in the size of the pulp chamber. Primary and secondary dentin secreted by odontoblasts, are characterized by closely packed dentinal tubules that span the entire thickness of the dentin $[1,3]$.

Dentin-pulp complex has regenerative potential that leads to the formation of tertiary dentin (reviewed by [3,4]. In response to mild environmental stimuli (attrition or early caries) preexisting live odontoblasts upregulate their secretory activity and secrete a tubular reactionary dentin matrix (reviewed by $[3,4]$. On the other hand, strong noxious stimuli (deep caries or pulp exposure) that lead to destruction of existing odontoblasts is followed by formation of reparative dentin secreted by a new generation of odontoblast-like cells derived from dental pulp $[3,4]$. Reparative dentin is an atubular structure containing cells trapped within the matrix also referred to as osteodentin. Reparative dentinogenesis occurs in the absence of inner dental epithelium and basement membrane and is thought to be dependent on multiple signaling molecules sequestrated in the dentin matrix [3,4].

Potential populations of cells within dental pulp capable of giving rise to the new generation of odontoblast-like cells during reparative dentinogenesis are numerous and include the cellrich layer of Höhl adjacent to the odontoblasts, undifferentiated mesenchymal cells and fibroblasts [3,4]. More recently, a putative post-natal stem cells in human adult third molars referred to as dental pulp stem cells (DPSC) were isolated and suggested to be among the potential population of cells involved in reparative dentinogenesis $[9,11]$. Transplantation of in vitro expanded DPSCs mixed with hydroxyapatite/tricalcium phosphate particles formed pulp-dentin like tissue complexes in immunocompromised mice $[9,11,12]$. In these studies DPSCs formed vascularized pulp-like tissue, surrounded by a layer of odontoblast- like cells expressing $D S P P$ without an active hematopoietic marrow $[9,11]$. These studies suggested that 
human adult dental pulp contained a small population of self-renewing, highly proliferative multipotent stem cells that reside within a larger population of more committed progenitors [13-15]. The same group also identified a potential mesenchymal stem cell (MSC) population derived from exfoliated deciduous human teeth (SHED), capable of extensive proliferation and multipotential differentiation suggesting their involvement in reparative dentinogenesis [16]. Further studies showed that the DPSCs expressed putative stem cell marker, STRO-1 perivascular cell marker CD146, and a proportion of these cells also co-expresses a smooth muscle actin and the pericyte-associated antigen 3G5 suggesting that a population of DPSCs may reside in this perivascular niche within the adult pulp [14,17].

MSC, first described in post-natal bone marrow [18], constitute a rare population of cells of non-hematopoietic origin that were identified by their adherence to plastic tissue culture dish and their fibroblastic morphology. When transplanted into an animal, these cells formed bone, cartilage, hematopoietic marrow, fat cells and the stroma that supports blood formation (reviewed by [19]). On the basis of their origin and their multipotency these cells were originally referred to as "bone marrow stromal stem cells" (BMSCs). More recently, these cells have been referred to as mesenchymal stem cells [19]. However, due to the lack of substantial evidence for the ability of BMSC to differentiate into non-skeletal cell types, it has been suggested that BMSC in bone marrow should be referred to as "skeletal stem cells" (reviewed by [19]).

An "MSC-like population" has been characterized and identified in various adult tissues using criteria established for BMSCs. The search for the identification of the "MSC-like population" in hard tissues has led to the discovery of "dental-MSC-like population" in post-natal human teeth including cells isolated from exfoliated deciduous teeth (SHED) [16], apical part of the papilla (SCAP) [20], dental follicle (DFSC) [21-23], and periodontal ligament (PDLSC) [24-27]. "Dental-MSC-like population" has also been obtained from pulps of impacted third molars $[10,28]$, fractured crowns [29] and supernumerary teeth [30].

More recently "stem cells" and/or "dental-MSC-like population" have also been isolated from pulps of deciduous and permanent teeth in various animal models [8,13,31-36]. Although these studies provided valuable information about the in vitro mineralization potential of pulp cells, the dentinogenic potential of these cells has not been fully examined and characterized.

Furthermore, there has been little attention to possible differences between the so-called "dental-MSC-like population" isolated from different types of teeth or in teeth at different stages of development and morphogenesis. Thus, the purpose of the present study was to examine and compare the mineralization and dentinogenic potentials of primary pulp cultures derived from unerupted (before root formation) and erupted (with almost complete root formation and after completion of crown morphogenesis) murine molars. We have examined the expression of various surface antigens shown to be expressed by "MSC-like population" and the multipotency of dental pulps of the erupted and unerupted murine molars.

\section{Materials and Methods \\ Primary dental pulp cultures}

The coronal portions of the pulps from first molars from 5 to 7 days old (P5-P7) suckling and P18-21 weanling CD1 mice with unerupted and erupted molars respectively were isolated and prepared for primary cultures as previously described [37,38]. Briefly, isolated pulps were digested with an enzyme mixture containing $0.05 \%$ trypsin-EDTA (Invitrogen, USA) and 1.5 $\mathrm{U} / \mathrm{ml}$ of Collagenase P (Roche, USA) in Phosphate Buffer saline (PBS) at $37^{\circ} \mathrm{C}$ for $30 \mathrm{~min}$ on a rocking platform. A single-cell suspension was obtained by passing the cells through narrowed Pasteur pipettes and a $70-\mu \mathrm{m}$ strainer. Cells were plated at a density of $5 \times 10^{5}$ cells/ $35-\mathrm{mm}$ well $\left(5 \times 10^{4} \mathrm{cell} / \mathrm{s} / \mathrm{cm}^{2}\right)$ and grown first in media containing Dulbecco's modified 
Eagles' medium (DMEM, Invitrogen), 20\% fetal bovine serum (FBS, Hyclone, USA), 40U/ $\mathrm{ml}$ of penicillin and $40 \mu \mathrm{g} / \mathrm{ml}$ of streptomycin, $0.1 \mathrm{mg} / \mathrm{ml}$ of Fungizone (Invitrogen) and $2 \mathrm{mM}$ Glutamine (Invitrogen) at $37^{\circ} \mathrm{C}$ and $5 \% \mathrm{CO}_{2}$. Three days later, the media was changed to media containing $10 \%$ FBS.

\section{Bone marrow stromal cell (BMSC) cultures}

BMSC were prepared from femurs and tibiae as described before [39-41] with minor modifications. Briefly, long bones were dissected from surrounding tissues. The epiphyseal growth plates were removed and the marrow was collected either by flushing with a 25 gauge needle (P18-21) [39,40] or rapid centrifugation at $9000 \mathrm{rpm}$ for $15 \mathrm{sec}$ (P5-7) [41] in minimal essential medium ( $\alpha$ MEM, Invitrogen) containing $40 \mathrm{U} / \mathrm{ml}$ Penicillin, $40 \mu \mathrm{g} / \mathrm{ml}$ streptomycin and $10 \%$ FCS. Single cell suspensions were prepared as described for pulp cells. BMSC were plated at a density of $5.2 \times 10^{6}$ cells $/ 35-\mathrm{mm}\left(5.2 \times 10^{5}\right.$ cells $\left./ \mathrm{cm}^{2}\right)$.

\section{Primary Calvarial Osteoblast (COB) Cultures}

Calvarial cells were isolated from 5-7-day-old suckling mice and prepared for culture as described before [42]. After removal of sutures and adherent mesenchymal tissues, calvaria were subjected to four sequential 15 -min enzyme digestions at $37^{\circ} \mathrm{C}$ in solution containing $0.05 \%$ trypsin-EDTA and $1.5 \mathrm{U} / \mathrm{ml}$ of Collagenase P in PBS. Cells released from the second to fourth digestions were pooled, centrifuged, resuspended in media, and plated at density of $2 \times 10^{5}$ cells $/ 35-\mathrm{mm}$ well $\left(2 \times 10^{4} \mathrm{cells} / \mathrm{cm}^{2}\right)$ in low glucose DMEM containing $10 \% \mathrm{FCS}, 40 \mathrm{U} /$ $\mathrm{ml}$ penicillin, $40 \mathrm{mg} / \mathrm{ml}$ streptomycin and $0.1 \mathrm{mg} / \mathrm{ml}$ of Fungizone.

\section{Induction, detection and quantification of mineralization in cultures}

Mineralization was induced in all primary cultures by addition of media containing $\alpha \mathrm{MEM}$, $10 \% \mathrm{FCS}, 40 \mathrm{U} / \mathrm{ml}$ penicillin, $40 \mathrm{mg} / \mathrm{ml}$ streptomycin, $50 \mu \mathrm{g} / \mathrm{ml}$ ascorbic acid, and $4 \mathrm{mM} \beta$ glycerol phosphate to confluent cultures (around day 7) [37,38]. Mineralization in various cultures was assayed using a modified von Kossa silver nitrate staining protocol $[43,44]$ to examine the phosphate deposits/contents respectively. After staining, images were acquired using a scanner and the area of mineralization (black precipitate) in each well was quantified using NIH ImageJ software and is represented as the percentage of total area analyzed as described before [45].

\section{Induction, detection and quantification of adipogenesis in cultures}

Adipogenesis was induced in primary cultures by addition of various adipogenic media $(0.5$ $\mu \mathrm{M}$ rosiglitazone and $1 \mu \mathrm{M}$ insulin [39]) $(1 \mu \mathrm{M}$ dexamethason, $0.5 \mu \mathrm{M}$ IBMX and $1 \mu \mathrm{M}$ insulin $[46,47])$ and $(0.5 \mu \mathrm{M}$ IBMX, $0.5 \mu \mathrm{M}$ hydrocortisone and $60 \mathrm{mM}$ indomethacin $[46,47])$ to confluent cultures. Oil Red O (ORO) staining was performed according to established protocol, to detect fat vacuoles [48]. After 1-hour of staining, wells were washed several times with water, air-dried and imaged.

\section{Induction, detection and quantification of chondrogenesis in cultures}

Chondrogenesis was examined using micromass cultures as previously described [49-52]. Briefly, freshly isolated cells were dissociated and plated as $20 \mu$ spots containing $2.5 \times 10^{5}$ cells $\left(2 \times 10^{7}\right.$ cells $\left./ \mathrm{ml}\right)$ in the center of 4 well plates. After 2 hours of incubation at $37^{\circ} \mathrm{C}$ media containing a 60:40 ratio of F12:DMEM, $10 \%$ fetal calf serum, $2 \mathrm{mM}$ glutamine, $200 \mu \mathrm{g} / \mathrm{ml}$ ascorbic acid, $100 \mathrm{U} / \mathrm{ml}$ penicillin, $100 \mu \mathrm{g} / \mathrm{ml}$ streptomycin, $0.25 \mu \mathrm{g} / \mathrm{ml}$ Fungizone with or without addition of $10 \mathrm{ng} / \mathrm{ml}$ of TGF- $\beta 3[50,52,53]$ was added and changed every other day. The accumulation of cartilage matrix was monitored histochemically by staining with Alcian Blue staining of the whole micromass cultures as [50,52-54]. 


\section{RNA extraction and analysis}

Total RNA was isolated in TRIzol reagent (Invitrogen, The Netherlands) according to the manufacturer's protocol and treated with RNase-free DNase. Isolated RNAs were reverse transcribed by Superscript II reverse transcriptase (Life Technologies) with oligo dT primers. Subsequent PCR amplifications were carried out using specific primers for GAPDH [55], osteocalcin (OC) [56], bone sialoprotein (BSP), dentin matrix protein 1 (DMP1) [57], Type I collagen (Colla1) [58], dentin sialophosphoprotein (DSPP) [32], peroxisome proliferationactivated receptor gamma 2 (PPAR $\gamma 2$ ) [59], and fatty acid binding protein 4 (FABP4, also known as aP2) [60], Sox9 [61] and Type II collagen (Col2a1) at conditions outlined in Supplemental Table 1. All RT-PCR reactions were performed at the linear phase and were carried out with at least three independent isolates of RNA. Controls for each reaction included no RT reaction, elimination of cDNA, primers, or Taq polymerase in the reactions. RT-PCR products were resolved on $1 \%$ agarose gel, stained with ethidium bromide, and digitally photographed.

The expression of $D S P P$ and $D M P 1$ in these cultures was also examined by quantitative polymerase chain reaction using $2 \mathrm{ng}$ of cDNA and $2 \mathrm{X}$ TaqMan universal PCR master mix (Applied Biosystems, USA) using a one-step program $\left(50^{\circ} \mathrm{C}\right.$ for $2 \mathrm{~min}$ and $95^{\circ} \mathrm{C}$ for $10 \mathrm{~min}$ ) followed by $95^{\circ} \mathrm{C}$ for $30 \mathrm{~s}$, and $59^{\circ} \mathrm{C}$ for $1 \mathrm{~min}$ for 40 cycles. TaqMan gene expression assays for DSPP (00515666_m1), DMPI (00803833_g1) and GAPDH (99999915_g1) were purchased from Applied Biosystems. Gene specific assays were run in quadruplicate in an iCycler thermocycler (BioRad, iCycler, USA) and analyzed using iQv3.1 post-run analysis software. The relative expression level for each target gene, normalized to GAPDH, was calculated using the comparative $C_{\mathrm{T}}$ method [62]; amplification efficiency for each TaqMan assay was determined using internal standard curves derived from purified amplicon, diluted 2 -fold ( $2 \mathrm{ng}-0.125 \mathrm{ng})$ assayed performed in duplicate. Values represent mean $\pm \mathrm{SE}$ and were determined from four independent experiments. Statistical significance was established by comparing the GAPDH-normalized values in Prism v5.1 (GraphPad software, USA).

\section{Flow Cytometric Analysis (FACS)}

Flow cytometry was done on a BD FacsCalibur cytometer and data were processed using Cell Quest software using various commercially available anti-mouse antibodies including CD45.2Biotin (104); CD117-APC (2B8); Sca-1-PE (D7); and CD90/Thy1.2-FITC (53-2.1).

Approximately $0.5-1 \times 10^{6}$ cells was incubated with pre-titrated antibodies (1:50-1:800), in the presence of rat $\operatorname{Ig}$ (when necessary), washed and resuspended in $300 \mu \mathrm{l}$ of staining medium containing $1 \mu \mathrm{g} / \mathrm{ml}$ of PI (propidium iodide) [58]. Between 20,000 and 100,000 cells was used for analysis.

\section{Immunocytochemistry}

Cultured cells were processed for immunocytochemistry using established protocol with some modifications [63]. Briefly, cells were fixed with $2 \%$ paraformaldehyde at $+4^{\circ} \mathrm{C}$ for $30 \mathrm{~min}$, washed with PBS $(3 \times 10 \mathrm{~min})$ and incubated with $3 \%$ milk in PBS to block nonspecific staining. Cells were then incubated with 1:200 dilution of Anti-DSP [LF-153 (kind gift from Dr. Larry Fisher)] for 1 hour at room temperature, washed with PBS $(3 \times 10 \mathrm{~min})$ and incubated with secondary antibody (Alexa Fluor 568 goat anti-rabbit, 1:800) (Invitrogen, USA) for 1 hour at room temperature). DAPI staining was used to stain the nuclei. To correlate the DSP signal with mineralized nodules, live cultures were incubated with Calcein Blue (30mM) (Sigma, USA) overnight at $37^{\circ} \mathrm{C}$ prior to processing for immunocytochemistry with anti-DSP. Images were obtained under fluorescent microscope using appropriate filters. 


\section{Confocal microscopy}

Cells cultured on coverslips were fixed and processed for immunocytochemistry and examination under confocal microscopy as described before. Cells were incubated with 1:400 dilution of anti-DSP antibody for $60 \mathrm{~min}$ at room temperature. After washing cells were incubated for $60 \mathrm{~min}$ at room temperature with a 1:800 dilution of secondary Alexa Fluor 568 goat anti-rabbit antibody. For nuclear detection, samples were incubated with TO-PRO-3 (Invitrogen, USA, 1:500 in PBS) for 30min. After staining cells were mounted to a slide with Prolong Gold anti-fade reagent (Invitrogen, A). Zeiss (Thornwood, NY) LSM 510 confocal laser scanning microscope with a $63 \times, 1.4$ numerical aperture oil immersion objective was used to collect images by simultaneous recording in the $568 \lambda$ and $647 \lambda$ channels .

\section{Detection of blood vessels}

Blood vessels in dental pulps of freshly isolated molars were analyzed using Orcein/Giemsa Staining [64] and immunohistochemistry with CD31 antibody for detection of endothelial cells in blood vessels [65]. Mandibles obtained from P5-7 and P18-21 mice were fixed, decalcified, and embedded in paraffin using standard protocols. Seven $\mu \mathrm{m}$ sections were stained for $30 \mathrm{~min}$ in Acid Orcein solution ( $0.2 \%$ Orcein, $0.6 \% \mathrm{HCl}$ in $70 \%$ ethanol) and counterstained overnight at room temperature with diluted Giemsa solution ( 2 drops of stock solution in $50 \mathrm{ml}$ of water, $\mathrm{pH}: 7)$. Adjacent sections were processed for immunohistochemistry. Sections were incubated overnight at $4{ }^{\circ} \mathrm{C}$ with 1:100 dilution of monoclonal rat-anti mouse CD31 (Abcam) and then for $30 \mathrm{~min}$ at room temperature with a 1:200 dilution of secondary biotinylated rabbit-anti-rat antibody followed by a $30 \mathrm{~min}$ incubation with avidin biotinylated horseradish peroxidase (Vector Labs). 3-3'-Diaminobenzidine (DAB Substrate Kit, Vector Labs) was used as the substrate for horseradish peroxidase.

\section{Statistical analysis}

Unpaired, two-tailed t-tests were performed to determine statistically significant differences and $\mathrm{p}<0.05$ was considered statistically significant.

\section{Results}

\section{Characterization of primary dental pulp cultures from unerupted (P5-7) molars}

The coronal portions of the pulps from unerupted molars of P5-7 mice, that contained no evidence of root formation were isolated and prepared for primary cultures. Freshly isolated pulps from unerupted molars contained approximately $1.12 \pm 0.1 \times 10^{4}$ cells per tooth $(n=3)$. Under culture conditions used in our studies, these cells proliferated rapidly (Supplemental Table 2) and reached confluence at day 7 (not shown).

Following the addition of minerlization inducing media containing $50 \mu \mathrm{g} / \mathrm{ml}$ of ascorbic acid and $4 \mathrm{mM} \beta$-glycerophosphate at day 7 , primary pulp cultures formed distinct multi-layered individual nodules. von Kossa staining showed first signs of mineralization around day 10 (Figure 1B) that increased thereafter (Figure 1C and D). Quantification of the mineralized area showed significant increases in the extent of mineralization with time in these cultures (Table 1, Figure 1A-D). At day 21 almost the entire culture dish was covered by a sheet of von Kossa stained mineralized tissue (Figure 1D).

Using similar culture conditions, we also examined the mineralization in primary cultures derived from bone marrow stromal cells (BMSC) (Figure 1E-H) and calvaria osteoblasts (COB) (Figure 1I-L) derived from P5-7 mice, as these cells are routinely used for studying mineralization in vitro. 
Under these conditions, the non-hematopoietic attached cells from bone marrow (BMSCs) proliferated and reached an optimal density at day 7 (Supplemental Table 2). The number of attached cells in the cultured BMSCs at 7 was higher than that in primary dental pulp cultures. In BMSCs, the mineralization occurred at around day 10 and increased thereafter ((Figure 1F$\mathrm{H}$ and Table 1). Compared to sheeth of mineralization seen in dental pulp cultures, BMSC cultures displayed patchy distribution of the mineralized nodules (Figure $1 \mathrm{G}$ and $1 \mathrm{H}$ ).

COB cultures also proliferated and reached confluence at day 7 (Supplemental Table 2). The number of attached cells at day 7 in COB cultures was comparable to the number of attached cells in primary dental pulp cultures. The onset of mineralization in COB cultures was around day 14 (Figure $1 \mathrm{~K}$ ). With time in culture, there were increases in the amount of mineralization (Figure 1I-L and Table 1). Similar to BMSC, COB cultures also displayed patchy distribution of the mineralized nodules (compare Figure $1 \mathrm{H}$ and $1 \mathrm{~L}$ ).

Next the patterns of expression of selected known markers for early and late stages of mineralization and odontoblast differentiation were examined in these cultures at various time points by semi-quantitative and quantitative RT-PCR analyses. In cultures derived from dental pulp of unerupted molars, high levels of Collal mRNA were detected at day 7 with slight decreases thereafter (days 14 and 21) (Figure 2A). BSP, DMP1, OC and DSPP mRNA were not detected at day 7 , were expressed at low levels at day 14 and increased significantly at day 21 (Figure 2B-E). The qPCR showed five folds increases in the levels of $D M P 1$ and $D S P P$ at day 21 as compared to day 14 respectively (Supplemental Table 3). The expression of DSPP in these cultures indicated the presence of odontoblasts-like cells secreting dentin mineralized matrix.

Analysis of BMSC and COB cultures showed that the temporal patterns of expression of Colla1, BSP, DMP1 and $O C$ were similar to those in dental pulp cultures (Figure 2A-D). The levels of $D M P 1$ were significantly increased at day 21 as compared to day 14 in these cultures (Supplemental Table 3). However, DSPP expression was not detected in BMSC or COB cultures at any time point (Figure 2 and Supplemental Table 3).

To gain further insight into the dentinogenic potential immunocytochemical analysis with antiDSP antibody was performed on cultures at days 14 and 21. In the dental pulp cultures, expression of DSP was detected in some but not all mineralized nodules (identified by Calcein Blue uptake) (Figures 3A-F). In these cultures DSP expression was detected in the extracellular matrix and cytoplasm but not in the nuclei (Figure 3G-I). Further quantitative analysis of the entire culture dish showed that in dental pulp cultures, approximately 50\% to 55\% of the mineralized nodules contained DSP expressing cells at days 14 and 21 respectively ( $n=3$, Figure 4A-F). Immunocytochemical analysis of BMSC (Figure 4G-I) and COB cultures (data not shown) showed the lack of DSP expression in these cultures that was consistent with the lack of expression of DSPP. Expression of DSP was not detected in control cultures (14 days old NIH3T3 fibroblast cultures incubated with anti-DSP and pulp cultures incubated with rabbit serum and secondary antibody) (data not shown).

Taken together, these data suggest that in vitro osteogenesis is shared by cells derived from dental pulps, BMSC and COB, whereas in vitro dentinogenesis is unique to cells derived from dental pulps. The in vitro differentiation of cells derived from dental pulp of murine molars into osteoblast- and odontoblast-like cells in the present study is consistent with our previous observation in explanted murine dental pulps [8] and in vitro osteogenesis in human pulp cells (reviewed by [15]).

Our finding that $D S P P$ and DSP are not expressed in osteoblasts differs from previous studies reporting low but detectable levels of DSPP and DSP in bone in vivo and in vitro [34,66-70]. These discrepancies most likely arise from differences in the sensitivity of the detection method 
used: previous studies detected low levels of DSPP in osteoblasts by semi-quantitative RT-

PCR after 40 cycles of amplification of approximately 10-100 ng of cDNA, while, in our study, $20 \mathrm{ng}$ (semi-quantitative) and $2 \mathrm{ng}$ (qRT-PCR) of cDNA were amplified for 30 and 40 cycles, respectively.

\section{Immunophenotype of cells in dental pulps}

We next examined in the expression of selected surface markers of the "MSC-like population" by flow cytometric analysis in freshly isolated dental pulps from unerupted murine molars and freshly isolated bone marrow of P5-7 mice. STRO-1 is the monoclonal antibody most extensively used for the characterization and isolation of multipotent "MSC-like population" [9,16,71-74]. However, STRO-1 antibody has been mostly effective in isolation of MSC from human and rat tissues [33,75,76]. Because of the limited and controversial reports on the specificity of the available STRO-1 antibody for mice cells [77], the MSC-like population in the dental pulp and bone marrow of mice were studied by examining the expression of CD90, CD117 and Sca-1 [78-86].

Freshly isolated pulp from unerupted molars contained very low representation of cells with hematopoietic lineage phenotypes (CD45), very high percentage of CD90+ and CD117+ cells, and low percentage of cells expressing Sca-1 (Figure 5 and Table 2A). Cells isolated from bone marrow of P5-7 mice, contained high percentage of CD45+ cells. The percentage of Sca-1+l CD45- cells in bone marrow was similar to that in dental pulp (Figure 5 and Table 2A). However, the percentage of CD90+/CD45- and CD117+/CD45- cells in bone marrow was significantly lower than that in dental pulp from unerupted molars (Figure 5 and Table 2A).

\section{Adipogenic and chondrogenic differentiation was not detected in primary dental pulp cultures from unerupted (P5-7) molars}

Our observations showed that dental pulp of the unerupted (P5-7) molars contained very little CD45+ cells and high percentage of cells expressing multiple surface antigens, suggested to be markers of "MSC-like cells". "MSC-like cells" in different tissues have been characterized by their potential and ability to differentiate into at least three; osteogenic, adipogenic and chondrogenic lineages [81]. Our observations showed that cells derived from dental pulp of unerupted molars have the ability to differentiate into bone- and dentin-like tissues indicating the osteo/dentinogenic potential of cells within dental pulp. To gain further insight into additional differentiation potential of dental pulp of unerupted molars, their adipogenic and chondrogenic potentials were examined.

Adipogenic differentiation was induced in confluent primary cultures by treatment with rosiglitazone and insulin, as described in Materials and Methods (Figure 6). In these experiments, BMSC were used as controls, as previous studies have shown extensive in vitro adipogenic potential of BMSC [87]. Under the adipogenic conditions used in our study, BMSC differentiate into a significant number of mature adipocytes as evidenced by accumulation of lipid-rich vacuoles within cells that stained with Oil Red O at day 10 (data not shown). These cells continued to develop and remained healthy in cultures up to 6-7 weeks (Figure 6A and A'). RT-PCR analysis of total RNA extracted from 6 weeks old BMSC cultures (Figure 6D) showed the expression of $P P A R \gamma 2$, expressed primarily in adipose tissue and an important regulator of adipogenesis [88] and $F A B P 4$, also known as $A P 2$, normally expressed by adipocytes and macrophages with important role in the lipid metabolism [89], in these cultures. Under these conditions, adipogenic differentiation was not detected in cultures derived from pulps of unerupted molars as evident by lack of detectable Oil Red $\mathrm{O}$ staining (Figure 6B and 6B') and the lack of expression of PPAR 2 and FABP4 (Figure 6D). Media supplemented with other adipogenic inducing reagents described in Materials and Methods did not change the extent and the sequence of adipogenesis in BMSC and confirmed the inability 
of the cells derived from dental pulps of the unerupted molars to undergo adipogenic differentiation (data not shown).

Chondrogenic differentiation was assayed using well-characterized micromass culture system with and without addition of TGF $\beta 3$ as described by others [49,50,52]. In these experiments, micromass cultures derived from E11 mandibular mesenchyme were used as control (Figure 7A and 7A'). Chondrogenic differentiation assayed by the accumulation of sulfated proteoglycans stained with Alcian Blue was apparent in micromass cultures derived from E11 mandibular mesenchyme at day 4 (data not shown). Over the next days, cartilage nodules increased in size, stained more intensely with Alcian Blue and new nodules appeared at the periphery of the culture (Figure 7A and 7A'). RT-PCR analysis showed expression of Sox9 (an early marker of chondrogenic differentiation) and Col2al (a marker for later stage of chondrogenic differentiation) in RNA isolated from 10 days old micromass cultures derived from E11 mandibular mesenchyme (Figure 7E).

Under these conditions, chondrogenic differentiation assayed by Alcian Blue staining and expression of Col2al was evident in BMSC micromass cultures after 14 days (Figure 7B, 7B' and 7E), but not in cultures derived from pulps of unerupted molars. (Figure 7C, 7C' and 7E). On the other hand, Sox 9 expression in cultures derived from dental pulp of unerupted molars and BMSC, suggesting the presence of chondroprogenitors (Figure 7E). Addition of media supplemented with TGF- $\beta 3$ enhanced the chondrogenesis in BMSC micromass cultures but did not induce chondrogenic differentiation by dental pulp from unerupted molars (data not shown). The chondrogenic potential of BMSC in micromass culture in our study is consistent with previous observations using pellet cultures for examination of chondrogenic potential (reviewed by $[19,53]$ ) and showed the feasibility of utilizing micromass cultures for these studies.

\section{Characterization of primary dental pulp cultures from P18-P21 (erupted) molars}

Previous studies have isolated and characterized a putative post-natal stem cell (DPSCs) [9] also referred to as "dental MSC-like population" from various human teeth [15]. To gain a better understanding of possible changes in characteristics of murine dental pulps after eruption, the coronal portion of pulps from erupted first molars from P18-P21 mice with almost complete root formation and after completion of crown morphogenesis were isolated and subjected to various analyses described for unerupted molars.

Freshly isolated pulps from erupted molars contained significantly lower number of cells than that in unerupted molars (approximately $0.18 \pm 0.01 \times 10^{4}$ cells per tooth, $\mathrm{n}=3$ ). FACS analysis of the freshly isolated cells from P18-21 (erupted) molars showed significant changes in the percentage of cells expressing various markers as compared to unerupted molars. This population contained significantly higher percentage of CD45+ cells (Table 2A) but lower percentage of CD90+/CD45-, and CD117+/CD45- cells (Table 2A). The percentage of Sca-1 $+/ \mathrm{CD} 45$ - was low and very similar to that in unerupted molars (Table 2A). The increases in the representation of CD45+ cells in erupted molars as compared to unerupted molars was consistent with increases in the vascularization in the pulps of erupted molars (Figure 8).

In primary cultures established from pulps of erupted molars (Figure 1M-P) cells proliferated and reached confluence at around day 7. The number of attached cells at day 7 in cultures derived from erupted molars were similar to those in unerupted molars (Supplemental Table 2). In these cultures the first sign of mineralization was around day 14 (Figure 1O) with increases thereafter. At day 14, these cultures contained a few mineralized nodules, which covered approximately $1 \%$ of the $35 \mathrm{~mm}$ culture dishes (Figure 10 and Table 1 ). The mineralized area in these cultures increased at day 21 to approximately 8\% (Figure 1P and Table 1). 
RT-PCR and immunocytochemical analyses of cultures derived from coronal portion of the pulp from erupted molars indicated that mineralization in these cultures also contained boneand dentin-like matrices (data not shown). These observations demonstrated significant reduction in cellularity, and delayed and reduced mineralization by primary pulp cultures from erupted molars (P18-21) as compared to unerupted molars (P5-7).

Under the same conditions, the mineralization potential of the BMSC derived from P18-21 mice (Figure 1Q-T and Table 1) were similar to that in BMSC cultures derived from P5-7 mice (Figure 1E-H and Table 1). FACS analysis showed that unlike in dental pulp, the percentages of cells expressing various markers were similar between bone marrow isolated from P5-7 and P18-21 mice (Table 2A). Furthermore, freshly isolated bone marrow isolated from P18-21 mice, contained significantly higher representation of CD45+, CD90+/CD45-, CD117+/CD45and Sca-1+/CD45- cells as compared to dental pulps from P18-21 mice (Table 2A). These observations suggested that changes in the mineralization potential and the expression of surface markers in cultures derived from pulp of erupted and unerupted molars were not related solely to chronological age, but to stage of morphogenesis and eruption of teeth.

We next examined the chondrogenic and adipogenic differentiation in cultures derived from pulps of erupted molars. When cells isolated from erupted molars were exposed to the adipogenic conditions, adipogenic differentiation assayed by Oil Red $\mathrm{O}$ staining was not apparent at day 10 and became apparent only at 6 weeks (Figure 6C and 6C'). RT-PCR analysis showed the expression of $P P A R \gamma 2$ and $F A B P 4$, in RNA extracted from 6 weeks old cultures of dental pulp from erupted molars (Figure 6D). The expression of PPAR 2 and FABP4 and the extent of Oil Red O staining in pulp cultures from erupted molars was significantly lower than that in BMSC cultures indicating reduced adipogenic differentiation in dental pulp cultures (Figure 6D).

Chondrogenic differentiation was evident in micromass cultures derived from erupted molars after 4 to 6 weeks (Figure 7D, 7D' and 7E). The levels of Col2al and Alcian Blue staining in these cultures were significantly lower than that in cultures from mandibular mesenchyme but similar to that in BMSC cultures (Figure 7E). The chondrogenic potential of dental pulp cells from erupted molars are consistent with previously reported results for DPSCs [90]. Taken together, these observations showed that dental pulps from erupted molars contain cells capable of giving rise to adipocytes and chondrocytes in vitro. However, this population of cells required a longer induction period to differentiate into adipocytes and chondrocytes and the frequency and degree of differentiation was significantly lower than that in BMSC.

We also examined the changes in the distribution of CD90, CD117, and Sca-1 during the first 7 days of cultures, prior to addition of various differentiation inducing medias in our study (Table 2B). FACS analysis showed increases in the percentage of CD90+/CD45- and Sca-1+/ CD45- after 7 days in cultures from erupted molar as compared to the freshly isolated cells (Table 2B). These observations suggested that CD90+ and Sca1+ population represent at least a fraction of "MSC-like population" in the dental pulp of the erupted molar. However, similar analysis in cultures derived from unerupted molars showed increases in the percentage of Sca-1 +/CD45- cells after 7 days in culture as compared to freshly isolated cells from unerupted molar pulps (Table 2B). These observations suggest that culture conditions support proliferation of the Sca-1+/CD45- subpopulation during the first 7 days. However, based on the inability of the cells isolated from unerupted molars to differentiate into adipocytes and chondrocytes, Sca-1+/CD45- population most likely does not represent MSC-like population in dental pulps of the erupted molars. 


\section{Discussion}

\section{Mineralization and dentinogenic potential of primary cultures derived from dental pulp}

Our study showed that freshly isolated cells from unerupted molars (P5-7) contained very little CD45+ cells and high percentage of CD90+/CD45-, CD117+/CD45- and Sca-+/CD45-. When subjected to mineralization inducing conditions primary cultures derived from dental pulp from unerupted molars displayed extensive in vitro mineralization potential. Further analysis showed that these cells differentiated into both osteoblast- and odontoblast-like cells secreting bone- and dentin-like matrices respectively. However, cultures derived from dental pulp of unerupted molars were not able to give rise to adipocytes and chondrocytes.

Based on our findings, we propose that dental pulps of the unerupted molars do not contain multipotent or "MSC-like" populations and contain primarily progenitor cells committed to dentinogenic/osteogenic lineage. The progenitor population in the pulps of unerupted molars includes the remaining dental papilla cells located in the cervical loops of the crown committed to odontoblast lineage. In the unerupted molars, this population is actively engaged in the formation of radicular dentin and primary dentin necessary for completion of crown morphogenesis [91]. It is well established that root development occurs after crown formation and is associated with the formation of Hertwig's epithelial root sheath (HERS). HERS is formed by the fusion of the inner and outer enamel epithelium in the cervical loop of the enamel organ. As the epithelial cells of the cervical loop proliferate apically to form HERS dental papilla cells in its close proximity differentiate into radicular odontoblasts while dental follicle differentiates into cementoblasts, osteoblasts, and fibroblasts of the PDL [92].

The behavior of cells from pulps of unerupted molars in our study suggests that previously identified "dental-MSC-like population" from pulps of teeth before complete morphogenesis and eruption represent a group of progenitor cells highly committed to the osteo/dentinogenic lineage and not necessarily "MSC-like population". Studies on cells derived from the apical papilla of human impacted molars with incomplete root formation [20] showed that these cells proliferated faster than DPSCs, exhibited higher telomerase activity and contained cells expressing markers of MSC including STRO-1+ (approximately 18\%), and CD90+ (approximately 95\%). The mineralization potential of cells derived from the human apical papilla was comparable to DPSC and BMSC, whereas the adipogenic potential was much less [20]. Interestingly, in this population, STRO-1+ cells co-expressed a variety of osteo/ dentinogenic markers and were termed stem cells from the apical papilla (SCAP) [20]. Our observations also show that markers of "MSC-like population" are also expressed by progenitor populations and thus cannot be used for isolation of MSC exclusively. Our results also argue that SCAP are mainly progenitor population.

Our findings also showed that freshly isolated cells from erupted molars (P18-21) contained approximately 37-38\% CD45+ cells and significantly lower representation of CD90+/CD45-, CD117+/CD45- and Sca-+/CD45- as compared to unerupted molars. There was also a significant reduction in the mineralization potential of the pulp cells derived from the coronal portion of erupted molars as compared to unerupted molars. However, despite these reductions, adipogenesis and chondrogenesis were observed in cultures derived from pulps of erupted molars. It is important to note that there were significant difference in the frequency and the degree of differentiation into adipocytes and chondrocytes in cultures from dental pulps of erupted molars and BMSC. Cell populations from the coronal portion of the erupted dental pulp required a longer induction period to differentiate into a very few adipocytes and chondrocytes as compared with BMSC. Based on these observations, we suggest that unlike the dental pulp cells from unerupted molars, dental pulp cells from the erupted molars have a broad differentiation potential. Dental pulp in vivo is composed of heterogeneous cell population containing several different cell types including fibroblasts, undifferentiated cells, 
nerve and blood vessels. However, adipocytes and chondrocytes are not among the cellular constituent of dental pulp. Thus, to further characterize the differentiation potential of cells within dental pulps from erupted murine molars in vivo transplantation assays, considered to be the gold standard for studying the differentiation potential of "MSC-like populations" from various sources, need to be used. Furthermore, additional studies using clonal cells are necessary to examine the differentiation potential and multipotency of single cell/clones derived from the dental pulp of murine erupted molars.

Based on these observations, we suggest dental pulp of the erupted murine molars contain a small population of multipotent stem cells that most likely is among the populations involved in formation of the new generation of odontoblasts-like cells giving rise to reparative dentin. This possibility is consistent with previous observations in human DPSC that (Gronthos et al, 2002). However, it is important to note that cells derived from dental pulps of human and various animal models have not been able to support hematopoiesis $[15,19]$.

Our observations showed a correlation between expression of marker of hematopoietic component, vascularization, root formation, eruption and the differentiation into various cell types in the pulps. Cells isolated from unerupted molars did not contain many CD45+ or blood vessels and gave rise to extensive amount of mineralized tissue but not adipocytes and chondrocytes. In contrast, pulps from erupted molars contained approximately 37-38\% CD45 + cells, numerous blood vessels and gave rise to limited amount of mineralized tissue, adipocytes and chondrocytes. These observations are suggestive of an association between appearance of the multipotent cells in the dental pulp with the arrival of blood vessels and associated structures (reviewed by [93-95]). This possibility is in line with several studies that suggested that putative stem cells in the dental pulp reside in a perivascular niche $[13,17]$.

Further experiments are in progress to examine this possibility by examining the distribution and the differentiation potential of cells expressing perivascular markers ( $\alpha$-smooth muscle actin, 3G5) [17,65]. Furthermore, in the light of evidence indicating the adipogenic and chondrogenic potentials of circulating progenitor cells in mice and guinea pig model respectively [96,97], the possibility of presence of limited number of multipotent progenitor/ stem population in the circulating blood in mice cannot be excluded .

\section{Comparison of dental pulp and BMSC}

Studies in human showed that BMSC share numerous characteristics with DPSC, in that both populations can differentiate into multiple mesenchymal cell lineages [10,95,98]. Furthermore, previous studies suggested that both cell populations could be used to generate dental structures under proper conditions $[9,10,12,99,100]$. It has been shown that BMSC are able to form cementum, PDL and alveolar bone after implantation into defective periodontal tissues [26].

However, despite these similarities, our observations showed the lack of dentinogenic potential in BMSC that together with previous studies $[101,102]$ point out to significant differences between these two populations. These findings together imply that BMSC may not be an optimal substitute for dental mesenchymal cells in tooth engineering. Similarly, the available evidence suggest that cells derived from dental pulp may not be a good substitute for skeletal stem cells derived from bone marrow of the long bones. The dental pulp and the bones in the craniofacial complex are primarily derived from cranial neural crest. On the other hand the appendicular or axial bones are derived from mesoderm. It has been shown that transplanted DPSC formed dentin-pulp complex that contained blood vessels but did not form the hematopoietic, fat containing marrow that present in the long bone and is formed by skeletal stem cells derived from bone marrow. These differences most likely reflect the embryonic origin and mode of ossification (intramembranous vs. endochondral ossification) between mesodermally derived bone and neural crest derived bones. The long bones contain appreciable large marrow spaces with hematopoietic components, whereas the bones in the craniofacial 
complex are more dense and contain less or smaller marrow spaces [103]. The formation of dentin by cells derived from dental pulp together with their inability to give rise to an organized hematopoietic marrow provide evidence that cells from dental pulp may not substitute for skeletal stem cells derived from bone marrow.

\section{Supplementary Material}

Refer to Web version on PubMed Central for supplementary material.

\section{Acknowledgments}

We thank all the individuals who provided reagents, valuable input and technical assistance in various aspects of these studies including Drs. Mark Kronenberg and Ivo Kalajzic, Mrs. Katie Lamothe, Miss. Diane Gran, and Mrs. Rodgers. We also thank Drs. Barbara Kream and William Upholt for critical review of this manuscript. This work was supported by a grant from National Institute of Health (NIDCR) to MM (DE016689).

Grant sponsor: National Institute of Health

\section{Literature Cited}

1. Lisi S, Peterkova R, Peterka M, Vonesch JL, Ruch JV, Lesot H. Tooth morphogenesis and pattern of odontoblast differentiation. Connect Tissue Res 2003;44(Suppl 1):167-70. [PubMed: 12952192]

2. Qin C, D'Souza R, Feng JQ. Dentin matrix protein 1 (DMP1): new and important roles for biomineralization and phosphate homeostasis. J Dent Res 2007;86:1134-41. [PubMed: 18037646]

3. Sloan AJ, Smith AJ. Stem cells and the dental pulp: potential roles in dentine regeneration and repair. Oral Dis 2007;13:151-7. [PubMed: 17305615]

4. Sloan AJ, Waddington RJ. Dental pulp stem cells: what, where, how? Int J Paediatr Dent 2009;19:6170. [PubMed: 19120509]

5. D'Souza RN, Cavender A, Sunavala G, Alvarez J, Ohshima T, Kulkarni AB, MacDougall M. Gene expression patterns of murine dentin matrix protein 1 (Dmp1) and dentin sialophosphoprotein (DSPP) suggest distinct developmental functions in vivo. J Bone Miner Res 1997;12:2040-9. [PubMed: 9421236]

6. Feng JQ, Luan X, Wallace J, Jing D, Ohshima T, Kulkarni AB, D'Souza RN, Kozak CA, MacDougall M. Genomic organization, chromosomal mapping, and promoter analysis of the mouse dentin sialophosphoprotein (Dspp) gene, which codes for both dentin sialoprotein and dentin phosphoprotein. J Biol Chem 1998;273:9457-64. [PubMed: 9545272]

7. MacDougall M, Simmons D, Luan X, Nydegger J, Feng J, Gu TT. Dentin phosphoprotein and dentin sialoprotein are cleavage products expressed from a single transcript coded by a gene on human chromosome 4. Dentin phosphoprotein DNA sequence determination. J Biol Chem 1997;272:835-42. [PubMed: 8995371]

8. Braut A, Kollar EJ, Mina M. Analysis of the odontogenic and osteogenic potentials of dental pulp in vivo using a Col1a1-2.3-GFP transgene. Int J Dev Biol 2003;47:281-92. [PubMed: 12755333]

9. Gronthos S, Brahim J, Li W, Fisher LW, Cherman N, Boyde A, DenBesten P, Robey PG, Shi S. Stem cell properties of human dental pulp stem cells. J Dent Res 2002;81:531-5. [PubMed: 12147742]

10. Gronthos S, Akintoye SO, Wang CY, Shi S. Bone marrow stromal stem cells for tissue engineering. Periodontol 2000 2006;41:188-95. [PubMed: 16686934]

11. Gronthos S, Mankani M, Brahim J, Robey PG, Shi S. Postnatal human dental pulp stem cells (DPSCs) in vitro and in vivo. Proc Natl Acad Sci U S A 2000;97:13625-30. [PubMed: 11087820]

12. Batouli S, Miura M, Brahim J, Tsutsui TW, Fisher LW, Gronthos S, Robey PG, Shi S. Comparison of stem-cell-mediated osteogenesis and dentinogenesis. J Dent Res 2003;82:976-81. [PubMed: 14630898]

13. Liu H, Gronthos S, Shi S. Dental pulp stem cells. Methods Enzymol 2006;419:99-113. [PubMed: 17141053] 
14. Shi S, Bartold PM, Miura M, Seo BM, Robey PG, Gronthos S. The efficacy of mesenchymal stem cells to regenerate and repair dental structures. Orthod Craniofac Res 2005;8:191-9. [PubMed: 16022721]

15. Huang GT, Gronthos S, Shi S. Mesenchymal stem cells derived from dental tissues vs. those from other sources: their biology and role in regenerative medicine. J Dent Res 2009;88:792-806. [PubMed: 19767575]

16. Miura M, Gronthos S, Zhao M, Lu B, Fisher LW, Robey PG, Shi S. SHED: stem cells from human exfoliated deciduous teeth. Proc Natl Acad Sci U S A 2003;100:5807-12. [PubMed: 12716973]

17. Shi S, Gronthos S. Perivascular niche of postnatal mesenchymal stem cells in human bone marrow and dental pulp. J Bone Miner Res 2003;18:696-704. [PubMed: 12674330]

18. Friedenstein AJ, Chailakhjan RK, Lalykina KS. The development of fibroblast colonies in monolayer cultures of guinea-pig bone marrow and spleen cells. Cell Tissue Kinet 1970;3:393-403. [PubMed: 5523063]

19. Bianco P, Robey PG, Simmons PJ. Mesenchymal stem cells: revisiting history, concepts, and assays. Cell Stem Cell 2008;2:313-9. [PubMed: 18397751]

20. Sonoyama W, Liu Y, Yamaza T, Tuan RS, Wang S, Shi S, Huang GT. Characterization of the apical papilla and its residing stem cells from human immature permanent teeth: a pilot study. J Endod 2008;34:166-71. [PubMed: 18215674]

21. Morsczeck C, Gotz W, Schierholz J, Zeilhofer F, Kuhn U, Mohl C, Sippel C, Hoffmann KH. Isolation of precursor cells (PCs) from human dental follicle of wisdom teeth. Matrix Biol 2005;24:155-65. [PubMed: 15890265]

22. Kemoun P, Laurencin-Dalicieux S, Rue J, Farges JC, Gennero I, Conte-Auriol F, Briand-Mesange F, Gadelorge M, Arzate H, Narayanan AS, Brunel G, Salles JP. Human dental follicle cells acquire cementoblast features under stimulation by BMP-2/-7 and enamel matrix derivatives (EMD) in vitro. Cell Tissue Res 2007;329:283-94. [PubMed: 17443352]

23. Handa K, Saito M, Tsunoda A, Yamauchi M, Hattori S, Sato S, Toyoda M, Teranaka T, Narayanan AS. Progenitor cells from dental follicle are able to form cementum matrix in vivo. Connect Tissue Res 2002;43:406-8. [PubMed: 12489190]

24. Gay IC, Chen S, MacDougall M. Isolation and characterization of multipotent human periodontal ligament stem cells. Orthod Craniofac Res 2007;10:149-60. [PubMed: 17651131]

25. Sonoyama W, Liu Y, Fang D, Yamaza T, Seo BM, Zhang C, Liu H, Gronthos S, Wang CY, Shi S, Wang S. Mesenchymal stem cell-mediated functional tooth regeneration in swine. PLoS One 2006;1:e79. [PubMed: 17183711]

26. Kawaguchi H, Hirachi A, Hasegawa N, Iwata T, Hamaguchi H, Shiba H, Takata T, Kato Y, Kurihara $\mathrm{H}$. Enhancement of periodontal tissue regeneration by transplantation of bone marrow mesenchymal stem cells. J Periodontol 2004;75:1281-7. [PubMed: 15515346]

27. Seo BM, Miura M, Gronthos S, Bartold PM, Batouli S, Brahim J, Young M, Robey PG, Wang CY, Shi S. Investigation of multipotent postnatal stem cells from human periodontal ligament. Lancet 2004;364:149-55. [PubMed: 15246727]

28. Takeda T, Tezuka Y, Horiuchi M, Hosono K, Iida K, Hatakeyama D, Miyaki S, Kunisada T, Shibata T, Tezuka K. Characterization of dental pulp stem cells of human tooth germs. J Dent Res 2008;87:676-81. [PubMed: 18573990]

29. Huang AH, Chen YK, Chan AW, Shieh TY, Lin LM. Isolation and characterization of human dental pulp stem/stromal cells from nonextracted crown-fractured teeth requiring root canal therapy. $\mathrm{J}$ Endod 2009;35:673-81. [PubMed: 19410081]

30. Huang AH, Chen YK, Lin LM, Shieh TY, Chan AW. Isolation and characterization of dental pulp stem cells from a supernumerary tooth. J Oral Pathol Med 2008;37:571-4. [PubMed: 18331285]

31. Mao JJ, Giannobile WV, Helms JA, Hollister SJ, Krebsbach PH, Longaker MT, Shi S. Craniofacial tissue engineering by stem cells. J Dent Res 2006;85:966-79. [PubMed: 17062735]

32. Iohara K, Nakashima M, Ito M, Ishikawa M, Nakasima A, Akamine A. Dentin regeneration by dental pulp stem cell therapy with recombinant human bone morphogenetic protein 2. J Dent Res 2004;83:590-5. [PubMed: 15271965]

33. Zhang W, Walboomers XF, Wolke JG, Bian Z, Fan MW, Jansen JA. Differentiation ability of rat postnatal dental pulp cells in vitro. Tissue Eng 2005;11:357-68. [PubMed: 15869416] 
34. Baba O, Qin C, Brunn JC, Jones JE, Wygant JN, McIntyre BW, Butler WT. Detection of dentin sialoprotein in rat periodontium. Eur J Oral Sci 2004;112:163-70. [PubMed: 15056114]

35. Cheng PH, Snyder B, Fillos D, Ibegbu CC, Huang AH, Chan AW. Postnatal stem/progenitor cells derived from the dental pulp of adult chimpanzee. BMC Cell Biol 2008;9:20. [PubMed: 18430234]

36. Iohara K, Zheng L, Ito M, Tomokiyo A, Matsushita K, Nakashima M. Side population cells isolated from porcine dental pulp tissue with self-renewal and multipotency for dentinogenesis, chondrogenesis, adipogenesis, and neurogenesis. Stem Cells 2006;24:2493-503. [PubMed: 16873765]

37. Balic A, Rodgers B, Mina M. Mineralization and expression of Col1a1-3.6GFP transgene in primary dental pulp culture. Cells Tissues Organs 2009;189:163-8. [PubMed: 18781059]

38. Balic A, Mina M. Analysis of developmental potentials of dental pulp in vitro using GFP transgenes. Orthod Craniofac Res 2005;8:252-8. [PubMed: 16238605]

39. Kalajzic Z, Li H, Wang LP, Jiang X, Lamothe K, Adams DJ, Aguila HL, Rowe DW, Kalajzic I. Use of an alpha-smooth muscle actin GFP reporter to identify an osteoprogenitor population. Bone 2008;43:501-10. [PubMed: 18571490]

40. Naganawa T, Xiao L, Abogunde E, Sobue T, Kalajzic I, Sabbieti M, Agas D, Hurley MM. In vivo and in vitro comparison of the effects of FGF-2 null and haploinsufficiency on bone formation in mice. Biochem Biophys Res Commun 2006;339:490-8. [PubMed: 16298332]

41. Dobson KR, Reading L, Haberey M, Marine X, Scutt A. Centrifugal isolation of bone marrow from bone: an improved method for the recovery and quantitation of bone marrow osteoprogenitor cells from rat tibiae and femurae. Calcif Tissue Int 1999;65:411-3. [PubMed: 10541770]

42. Wang YH, Liu Y, Rowe DW. Effects of transient PTH on early proliferation, apoptosis, and subsequent differentiation of osteoblast in primary osteoblast cultures. Am J Physiol Endocrinol Metab 2007;292:E594-603. [PubMed: 17032929]

43. Kalajzic I, Kalajzic Z, Kaliterna M, Gronowicz G, Clark SH, Lichtler AC, Rowe D. Use of type I collagen green fluorescent protein transgenes to identify subpopulations of cells at different stages of the osteoblast lineage. J Bone Miner Res 2002;17:15-25. [PubMed: 11771662]

44. Wang YH, Liu Y, Maye P, Rowe DW. Examination of mineralized nodule formation in living osteoblastic cultures using fluorescent dyes. Biotechnol Prog 2006;22:1697-701. [PubMed: 17137320]

45. Chang MK, Raggatt LJ, Alexander KA, Kuliwaba JS, Fazzalari NL, Schroder K, Maylin ER, Ripoll VM, Hume DA, Pettit AR. Osteal tissue macrophages are intercalated throughout human and mouse bone lining tissues and regulate osteoblast function in vitro and in vivo. J Immunol 2008;181:123244. [PubMed: 18606677]

46. Dorheim MA, Sullivan M, Dandapani V, Wu X, Hudson J, Segarini PR, Rosen DM, Aulthouse AL, Gimble JM. Osteoblastic gene expression during adipogenesis in hematopoietic supporting murine bone marrow stromal cells. J Cell Physiol 1993;154:317-28. [PubMed: 8425912]

47. Gregoire FM. Adipocyte differentiation: from fibroblast to endocrine cell. Exp Biol Med (Maywood) 2001;226:997-1002. [PubMed: 11743135]

48. Tang QQ, Otto TC, Lane MD. CCAAT/enhancer-binding protein beta is required for mitotic clonal expansion during adipogenesis. Proc Natl Acad Sci U S A 2003;100:850-5. [PubMed: 12525691]

49. Ji YH, Ji JL, Sun FY, Zeng YY, He XH, Zhao JX, Yu Y, Yu SH, Wu W. Quantitative proteomic analysis of chondrogenic differentiation of C3H10T1/2 mesenchymal stem cells by iTRAQ labeling coupled with online 2D-LC/MS/MS. Mol Cell Proteomics 2009;9:550-64. [PubMed]. [PubMed: 20008835]

50. Xu Y, Balooch G, Chiou M, Bekerman E, Ritchie RO, Longaker MT. Analysis of the material properties of early chondrogenic differentiated adipose-derived stromal cells (ASC) using an in vitro three-dimensional micromass culture system. Biochem Biophys Res Commun 2007;359:311-6. [PubMed: 17543281]

51. Scharstuhl A, Schewe B, Benz K, Gaissmaier C, Buhring HJ, Stoop R. Chondrogenic potential of human adult mesenchymal stem cells is independent of age or osteoarthritis etiology. Stem Cells 2007;25:3244-51. [PubMed: 17872501]

52. Toh WS, Lee EH, Richards M, Cao T. In vitro derivation of chondrogenic cells from human embryonic stem cells. Methods Mol Biol 2101;584:317-31. [PubMed]. [PubMed: 19907985] 
53. Koelling S, Miosge N. Stem cell therapy for cartilage regeneration in osteoarthritis. Expert Opin Biol Ther 2009;9:1399-405. [PubMed: 19793003]

54. Gluhak J, Mais A, Mina M. Tenascin-C is associated with early stages of chondrogenesis by chick mandibular ectomesenchymal cells in vivo and in vitro. Dev Dyn 1996;205:24-40. [PubMed: 8770549]

55. Yang M, Kream BE. Calcitonin induces expression of the inducible cAMP early repressor in osteoclasts. Endocrine 2008;33:245-53. [PubMed: 19016003]

56. Schilling AF, Schinke T, Munch C, Gebauer M, Niemeier A, Priemel M, Streichert T, Rueger JM, Amling M. Increased bone formation in mice lacking apolipoprotein E. J Bone Miner Res 2005;20:274-82. [PubMed: 15647822]

57. Yuasa K, Fukumoto S, Kamasaki Y, Yamada A, Fukumoto E, Kanaoka K, Saito K, Harada H, Arikawa-Hirasawa E, Miyagoe-Suzuki Y, Takeda S, Okamoto K, Kato Y, Fujiwara T. Laminin alpha2 is essential for odontoblast differentiation regulating dentin sialoprotein expression. J Biol Chem 2004;279:10286-92. [PubMed: 14681233]

58. Boban I, Jacquin C, Prior K, Barisic-Dujmovic T, Maye P, Clark SH, Aguila HL. The 3.6 kb DNA fragment from the rat Colla1 gene promoter drives the expression of genes in both osteoblast and osteoclast lineage cells. Bone 2006;39:1302-12. [PubMed: 16938497]

59. Jackson SM, Demer LL. Peroxisome proliferator-activated receptor activators modulate the osteoblastic maturation of MC3T3-E1 preosteoblasts. FEBS Lett 2000;471:119-24. [PubMed: 10760525]

60. Deng J, Hua K, Caveney EJ, Takahashi N, Harp JB. Protein inhibitor of activated STAT3 inhibits adipogenic gene expression. Biochem Biophys Res Commun 2006;339:923-31. [PubMed: 16329991]

61. Bi W, Huang W, Whitworth DJ, Deng JM, Zhang Z, Behringer RR, de Crombrugghe B. Haploinsufficiency of Sox 9 results in defective cartilage primordia and premature skeletal mineralization. Proc Natl Acad Sci U S A 2001;98:6698-703. [PubMed: 11371614]

62. Schmittgen TD, Livak KJ. Analyzing real-time PCR data by the comparative C(T) method. Nat Protoc 2008;3:1101-8. [PubMed: 18546601]

63. Mulrooney JP, Hong T, Grabel LB. Serine 785 phosphorylation of the beta1 cytoplasmic domain modulates beta1 A-integrin-dependent functions. J Cell Sci 2001;114:2525-33. [PubMed: 11559760]

64. Pinkus H, Hunter R. Simplified acid orcein and Giemsa technique for routine staining of skin sections. Arch Dermatol 1960;82:699-700. [PubMed: 13735864]

65. Sacchetti B, Funari A, Michienzi S, Di Cesare S, Piersanti S, Saggio I, Tagliafico E, Ferrari S, Robey PG, Riminucci M, Bianco P. Self-renewing osteoprogenitors in bone marrow sinusoids can organize a hematopoietic microenvironment. Cell 2007;131:324-36. [PubMed: 17956733]

66. Qin C, Brunn JC, Baba O, Wygant JN, McIntyre BW, Butler WT. Dentin sialoprotein isoforms: detection and characterization of a high molecular weight dentin sialoprotein. Eur J Oral Sci 2003;111:235-42. [PubMed: 12786955]

67. Ogbureke KU, Fisher LW. Renal expression of SIBLING proteins and their partner matrix metalloproteinases (MMPs). Kidney Int 2005;68:155-66. [PubMed: 15954904]

68. Baba O, Qin C, Brunn JC, Wygant JN, McIntyre BW, Butler WT. Colocalization of dentin matrix protein 1 and dentin sialoprotein at late stages of rat molar development. Matrix Biol 2004;23:3719. [PubMed: 15533758]

69. Qin C, Baba O, Butler WT. Post-translational modifications of sibling proteins and their roles in osteogenesis and dentinogenesis. Crit Rev Oral Biol Med 2004;15:126-36. [PubMed: 15187031]

70. Yuan G, Wang Y, Gluhak-Heinrich J, Yang G, Chen L, Li T, Wu LA, Chen Z, Macdougall M, Chen S. Tissue-specific expression of dentin sialophosphoprotein (DSPP) and its polymorphisms in mouse tissues. Cell Biol Int 2009;33:816-29. [PubMed]. [PubMed: 19450697]

71. Dennis JE, Carbillet JP, Caplan AI, Charbord P. The STRO-1+ marrow cell population is multipotential. Cells Tissues Organs 2002;170:73-82. [PubMed: 11731697]

72. Gronthos S, Graves SE, Ohta S, Simmons PJ. The STRO-1+ fraction of adult human bone marrow contains the osteogenic precursors. Blood 1994;84:4164-73. [PubMed: 7994030]

73. Simmons PJ, Torok-Storb B. Identification of stromal cell precursors in human bone marrow by a novel monoclonal antibody, STRO-1. Blood 1991;78:55-62. [PubMed: 2070060] 
74. Laino G, d'Aquino R, Graziano A, Lanza V, Carinci F, Naro F, Pirozzi G, Papaccio G. A new population of human adult dental pulp stem cells: a useful source of living autologous fibrous bone tissue (LAB). J Bone Miner Res 2005;20:1394-402. [PubMed: 16007337]

75. Yang X, van den Dolder J, Walboomers XF, Zhang W, Bian Z, Fan M, Jansen JA. The odontogenic potential of STRO-1 sorted rat dental pulp stem cells in vitro. J Tissue Eng Regen Med 2007;1:6673. [PubMed: 18038394]

76. Yang X, Zhang W, van den Dolder J, Walboomers XF, Bian Z, Fan M, Jansen JA. Multilineage potential of STRO-1+ rat dental pulp cells in vitro. J Tissue Eng Regen Med 2007;1:128-35. [PubMed: 18038401]

77. Kemoun P, Laurencin-Dalicieux S, Rue J, Vaysse F, Romeas A, Arzate H, Conte-Auriol F, Farges JC, Salles JP, Brunel G. Localization of STRO-1, BMP-2/-3/-7, BMP receptors and phosphorylated Smad-1 during the formation of mouse periodontium. Tissue Cell 2007;39:257-66. [PubMed: 17662325]

78. Bobis S, Jarocha D, Majka M. Mesenchymal stem cells: characteristics and clinical applications. Folia Histochem Cytobiol 2006;44:215-30. [PubMed: 17219716]

79. Hombach-Klonisch S, Panigrahi S, Rashedi I, Seifert A, Alberti E, Pocar P, Kurpisz M, SchulzeOsthoff K, Mackiewicz A, Los M. Adult stem cells and their trans-differentiation potential-perspectives and therapeutic applications. J Mol Med 2008;86:1301-14. [PubMed: 18629466]

80. Pittenger MF, Mackay AM, Beck SC, Jaiswal RK, Douglas R, Mosca JD, Moorman MA, Simonetti DW, Craig S, Marshak DR. Multilineage potential of adult human mesenchymal stem cells. Science 1999;284:143-7. [PubMed: 10102814]

81. Prockop DJ. Marrow stromal cells as stem cells for nonhematopoietic tissues. Science 1997;276:714. [PubMed: 9082988]

82. Eslaminejad MB, Nadri S, Hosseini RH. Expression of Thy 1.2 surface antigen increases significantly during the murine mesenchymal stem cells cultivation period. Dev Growth Differ 2007;49:351-64. [PubMed: 17501911]

83. Nadri S, Soleimani M, Hosseni RH, Massumi M, Atashi A, Izadpanah R. An efficient method for isolation of murine bone marrow mesenchymal stem cells. Int J Dev Biol 2007;51:723-9. [PubMed: 17939119]

84. Liu ZJ, Zhuge Y, Velazquez OC. Trafficking and differentiation of mesenchymal stem cells. J Cell Biochem 2009;106:984-91. [PubMed: 19229871]

85. Nemeth K, Mayer B, Mezey E. Modulation of bone marrow stromal cell functions in infectious diseases by toll-like receptor ligands. J Mol Med 2010;88:5-10. [PubMed]. [PubMed: 19756450]

86. Popp FC, Renner P, Eggenhofer E, Slowik P, Geissler EK, Piso P, Schlitt HJ, Dahlke MH. Mesenchymal stem cells as immunomodulators after liver transplantation. Liver Transpl 2009;15:1192-8. [PubMed: 19790154]

87. Muruganandan S, Roman AA, Sinal CJ. Adipocyte differentiation of bone marrow-derived mesenchymal stem cells: cross talk with the osteoblastogenic program. Cell Mol Life Sci 2009;66:236-53. [PubMed: 18854943]

88. Zieleniak A, Wojcik M, Wozniak LA. Structure and physiological functions of the human peroxisome proliferator-activated receptor gamma. Arch Immunol Ther Exp (Warsz) 2008;56:331-45. [PubMed: 18836859]

89. Krusinova, E.; Pelikanova, T. Diabetes Res Clin Pract. Vol. 82. Suppl 2: 2008. Fatty acid binding proteins in adipose tissue: a promising link between metabolic syndrome and atherosclerosis?; p. S127-34.

90. Zhang W, Walboomers XF, Shi S, Fan M, Jansen JA. Multilineage differentiation potential of stem cells derived from human dental pulp after cryopreservation. Tissue Eng 2006;12:2813-23. [PubMed: 17518650]

91. Thesleff I, Tummers M. Stem cells and tissue engineering: prospects for regenerating tissues in dental practice. Med Princ Pract 2003;12(Suppl 1):43-50. [PubMed: 12707500]

92. Luan X, Ito Y, Diekwisch TG. Evolution and development of Hertwig's epithelial root sheath. Dev Dyn 2006;235:1167-80. [PubMed: 16450392] 
93. Diaz-Flores L, Gutierrez R, Madrid JF, Varela H, Valladares F, Acosta E, Martin-Vasallo P, DiazFlores L Jr. Pericytes. Morphofunction, interactions and pathology in a quiescent and activated mesenchymal cell niche. Histol Histopathol 2009;24:909-69. [PubMed: 19475537]

94. Diaz-Flores L Jr. Gutierrez R, Madrid JF, Varela H, Valladares F, Diaz-Flores L. Adult stem cells and repair through granulation tissue. Front Biosci 2009;14:1433-70. [PubMed: 19273139]

95. Caplan AI. Why are MSCs therapeutic? New data: new insight. J Pathol 2009;217:318-24. [PubMed: 19023885]

96. Crossno JT Jr. Majka SM, Grazia T, Gill RG, Klemm DJ. Rosiglitazone promotes development of a novel adipocyte population from bone marrow-derived circulating progenitor cells. J Clin Invest 2006;116:3220-8. [PubMed: 17143331]

97. Kuznetsov SA, Mankani MH, Leet AI, Ziran N, Gronthos S, Robey PG. Circulating connective tissue precursors: extreme rarity in humans and chondrogenic potential in guinea pigs. Stem Cells 2007;25:1830-9. [PubMed: 17464083]

98. Shi S, Robey PG, Gronthos S. Comparison of human dental pulp and bone marrow stromal stem cells by cDNA microarray analysis. Bone 2001;29:532-9. [PubMed: 11728923]

99. Ohazama A, Modino SA, Miletich I, Sharpe PT. Stem-cell-based tissue engineering of murine teeth. J Dent Res 2004;83:518-22. [PubMed: 15218039]

100. Hu B, Unda F, Bopp-Kuchler S, Jimenez L, Wang XJ, Haikel Y, Wang SL, Lesot H. Bone marrow cells can give rise to ameloblast-like cells. J Dent Res 2006;85:416-21. [PubMed: 16632753]

101. Yu J, Wang Y, Deng Z, Tang L, Li Y, Shi J, Jin Y. Odontogenic capability: bone marrow stromal stem cells versus dental pulp stem cells. Biol Cell 2007;99:465-74. [PubMed: 17371295]

102. Nomiyama K, Kitamura C, Tsujisawa T, Nagayoshi M, Morotomi T, Terashita M, Nishihara T. Effects of lipopolysaccharide on newly established rat dental pulp-derived cell line with odontoblastic properties. J Endod 2007;33:1187-91. [PubMed: 17889687]

103. Artico M, Ferrante L, Pastore FS, Ramundo EO, Cantarelli D, Scopelliti D, Iannetti G. Bone autografting of the calvaria and craniofacial skeleton: historical background, surgical results in a series of 15 patients, and review of the literature. Surg Neurol 2003;60:71-9. [PubMed: 12865021] 


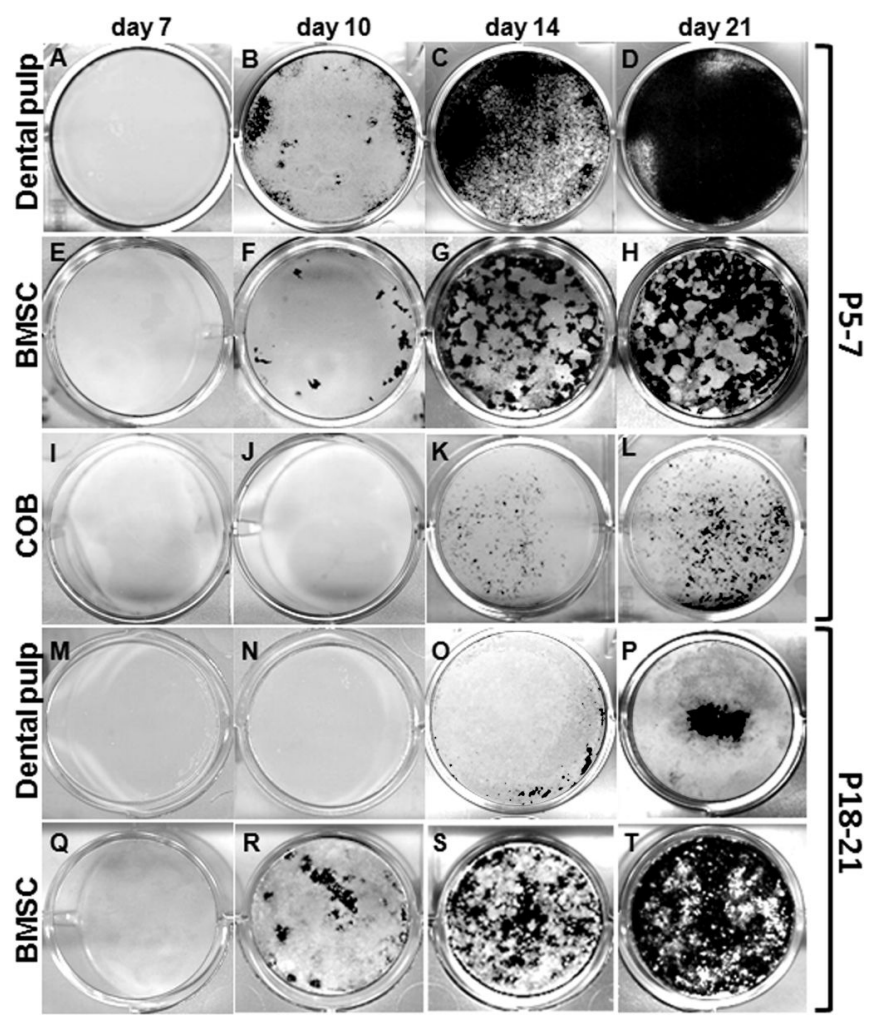

Figure 1. Mineralization potential of primary cultures derived from dental pulp, BMSC and calvarial osteoblasts established from P5-7 and P18-21 mice

von Kossa staining of mineralized tissue in primary cultures established from dental pulp (AD and M-P), BMSC (E-H and Q-T) and calvaria osteoblasts (I-L) of P5-7 (A-L) and P18-21 (M-T) mice at various time points. In cultures derived from dental pulp and BMSC isolated from P5-7, the first sign of mineralization is at day 10 (B, F) and increased at days 14 and 21 $(\mathrm{D}, \mathrm{H})$. In cultures derived from calvaria osteoblasts from P5-7 mice, the first sign of mineralization is at day $14(\mathrm{~K})$. In cultures derived from dental pulp isolated from P18-21 (M$\mathrm{P})$, the first sign of mineralization is at day $14(\mathrm{O})$ with increased at days 14 and $21(\mathrm{P})$. Note the reduced amount of mineralization in these cultures as compared to cultures derived from pulps from P5-7 (A-D). 
A

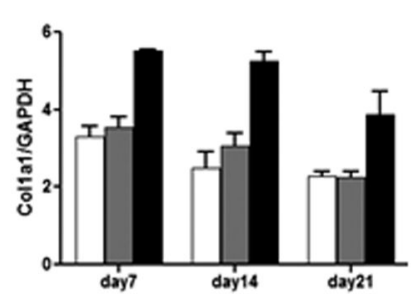

D

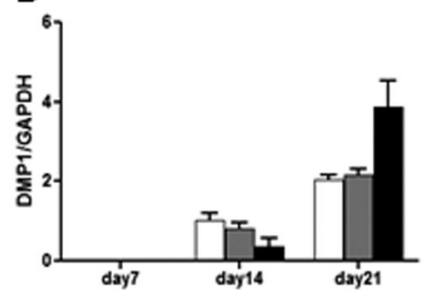

B

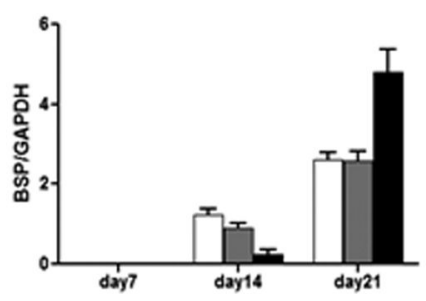

E

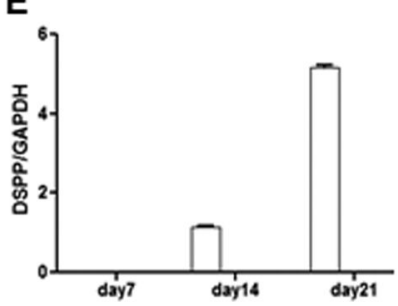

C

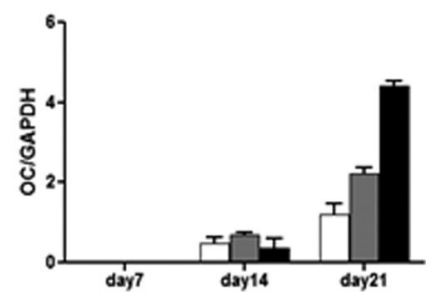

$\square$ dental pulp

$\square$ calvaria

bone marrow

Figure 2. Characterization of mineralized matrix in primary cultures derived from dental pulp, BMSC and COB of P5-7 mice by RT-PCR

In all cultures, the expression of Collal (A) was detected at the highest levels at day 7 with decreases thereafter. In all cultures, expression of $B S P(\mathrm{~B}), O C(\mathrm{C})$ and $D M P 1$ (D) were not detected at day 7, appeared at day 14 and increased at day 21. Expression of $D S P P(\mathrm{E})$ was detected only in dental pulp cultures. In cultures from dental pulp DSPP expression was detected first at day 14 and increased at day 21 . Values represent mean value \pm S.E of four independent experiments. 

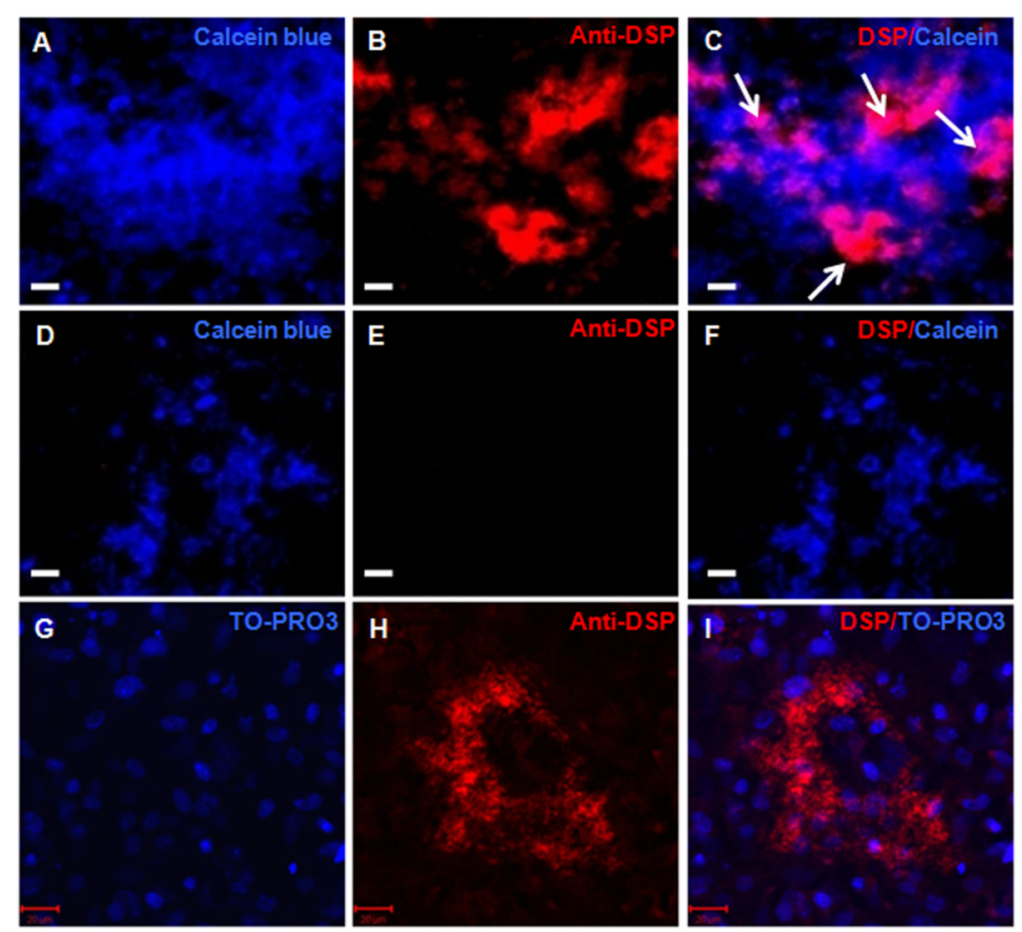

Figure 3. Expression of DSP in mineralized matrix in vitro

Epifluorescence images of 14 days old primary dental pulp cultures stained with Calcein blue (A, D), TO-PRO3 (G) and anti-DSP antibody (B, E, H) C, F, and I represent overlay of the two images generated by AxioVision software.

A-C represent the expression of DSP (indicated by white arrows in C) in mineralized nodules stained with Calcein Blue.

D-E demonstrate the lack of expression of DSP in another mineralized nodule in the same culture.

G-I: Confocal images of 14 days old primary dental pulp cultures showing DSP expression in the cytoplasm and in the extracellular matrix, but not in the nuclei (I). Scale bars in all images $=20 \mu \mathrm{m}$. 


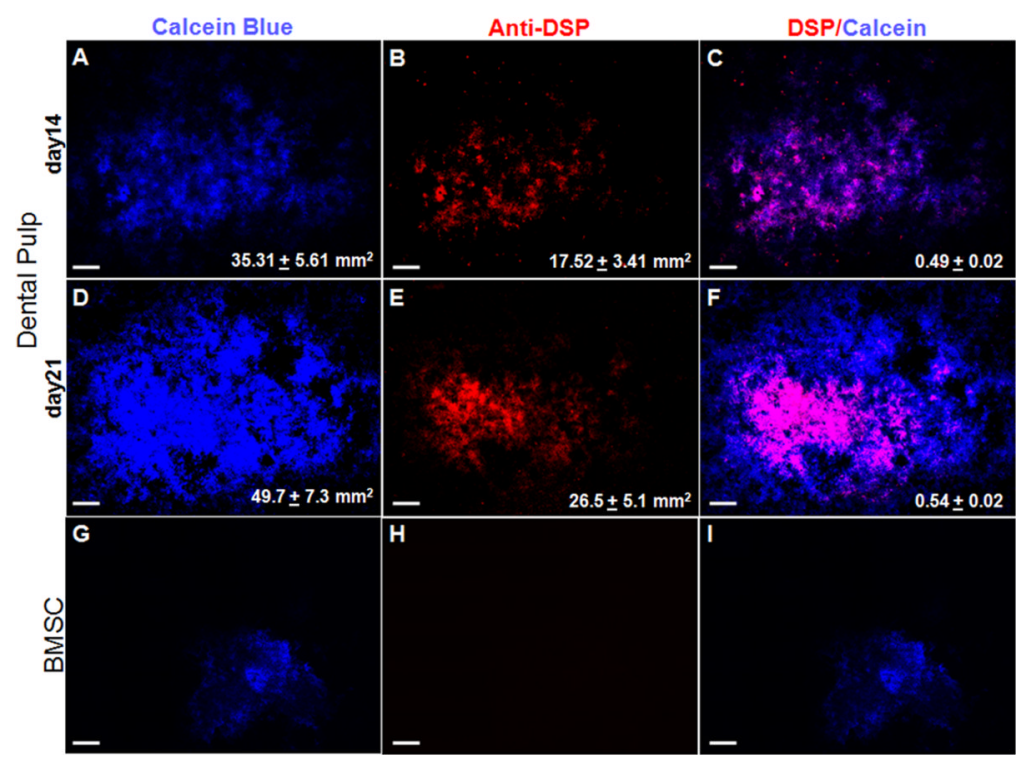

Figure 4. Quantification of the dentinogenic potential in the primary dental pulp culture Cultures from dental pulp (A-F) and BMSC (G-I) of P5-7 mice were stained with Calcein Blue $(\mathrm{A}, \mathrm{D}, \mathrm{G})$ and anti-DSP antibody $(\mathrm{B}, \mathrm{E}, \mathrm{H})$. Note that the expression of DSP in mineralized nodules in cultures from dental pulp $(\mathrm{B}, \mathrm{E})$, but not in BMSC $(\mathrm{H}) . \mathrm{C}, \mathrm{F}$ and I represent overlay of the two images generated by AxioVision software. DSP expression is not detected in all the mineralized areas of the dental pulp cultures. Values in figures A and D represent mean \pm SE of the total area of cultures stained with Calcein Blue. Values in B and E represent mean $\pm S E$ of the total area of cultures stained with anti-DSP antibody. Values in $\mathrm{C}$ and $\mathrm{F}$ represents the ratio of DSP+ area to Calcein Blue+ areas. Values are mean \pm S.E from at least three independent experiments. Scale bar in all images $=1 \mathrm{~mm}$. 


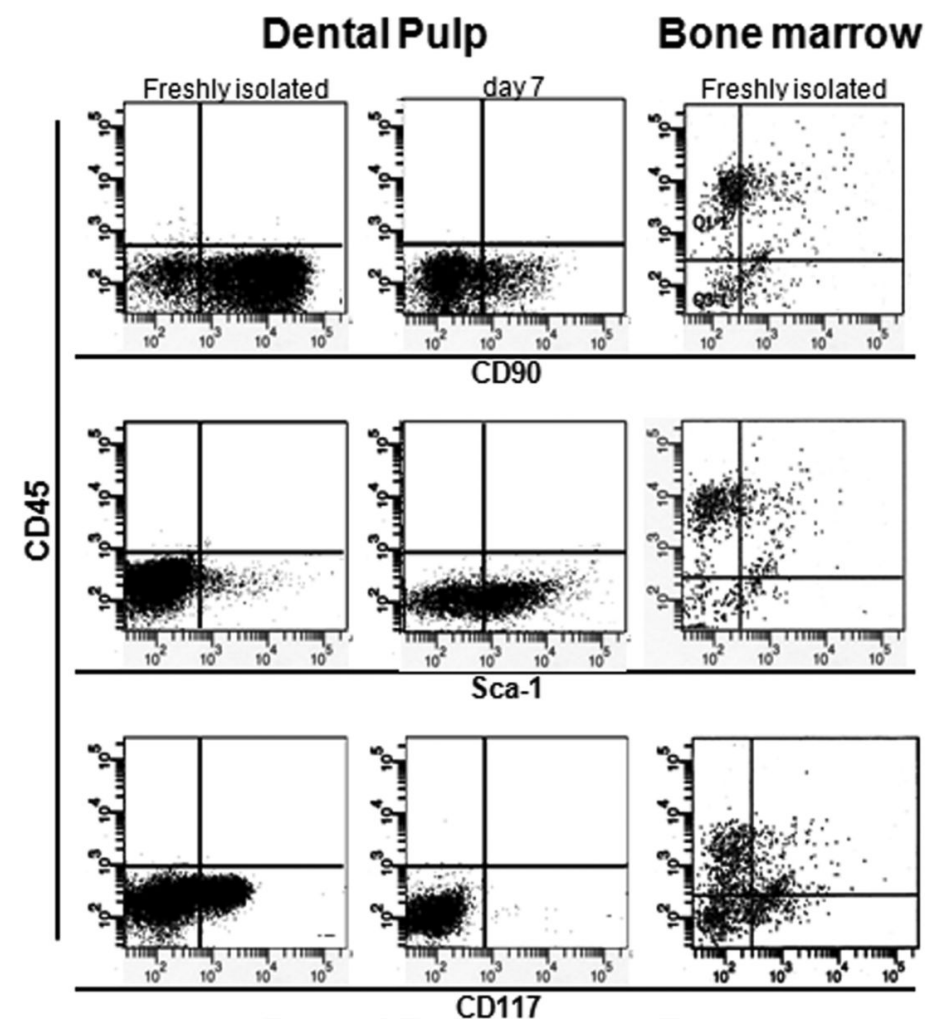

Figure 5. Characterization of the expression of cell surface markers

Flow cytometry analysis of the expression of CD45 (y axis), CD90, CD117 and Sca-1 (X-axes) cell surface markers in freshly isolated and cultured dental pulp cells and freshly isolated bone marrow from P5-7 mice. Note that freshly isolated dental pulp cells from unerupted molars contained high number of cells expressing markers of MSC (CD90, CD117 and Sca-1), and very low number of cells expressing hematopoietic stem cell marker CD45. On the other hand, cells isolated from bone marrow contained high number of CD45+, and moderate number of cells expressing CD90, CD117 and Sca-1. During the 7 days in culture there were increases in the number of Sca-1+ and decreases in the number of CD90+ and CD117+ cells. 


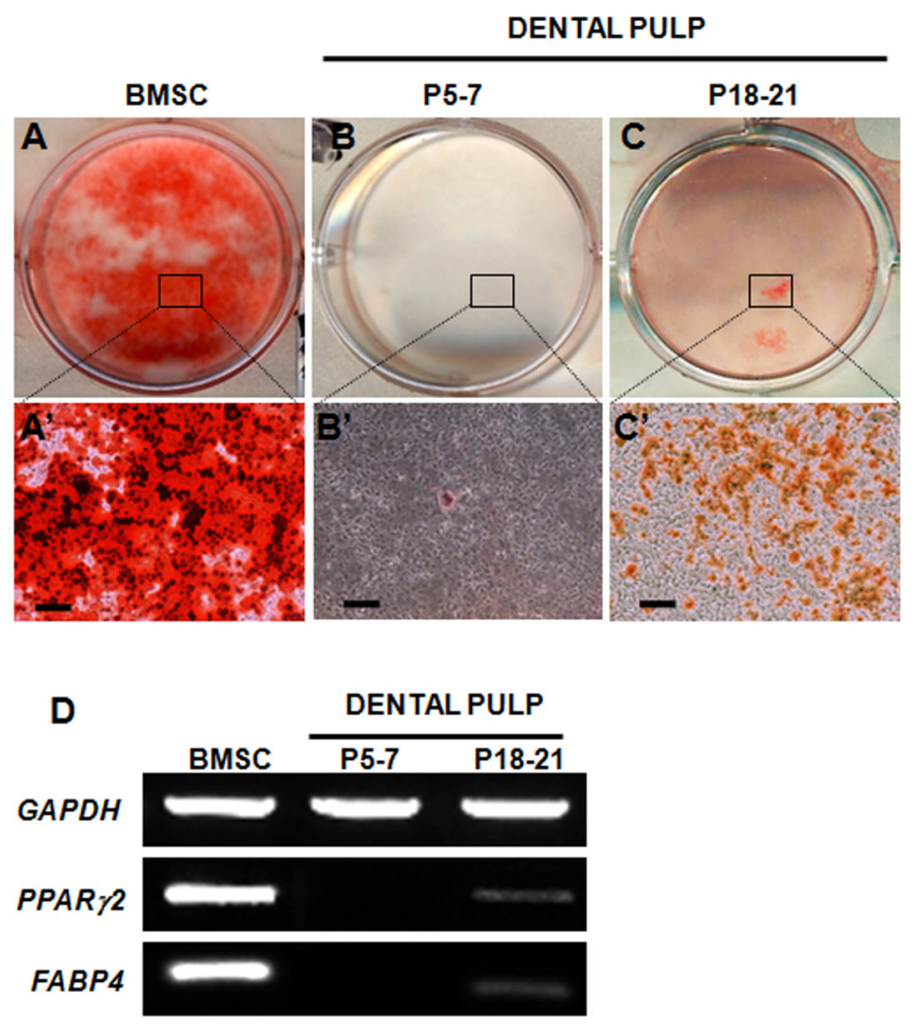

Figure 6. Adipogenic differentiation by cultures derived from dental pulp A-C represent images of representative cultures after 6 weeks from BMSC (A) and dental pulp from unerupted (P5-7) (B) and erupted (P18-21) molars (C) stained with Oil Red O. A'-C' represent bright field images of the areas of cultures indicated in boxes showing lipid vacuoles stained with ORO. Scale bars in A'-C'=100 $\mu \mathrm{m}$.

(D) RT-PCR analysis of expression of FABP4 and PPAR 2, markers of adipogenesis in these cultures. Note the high levels of $P P A R \gamma 2$ and $F A B P 4$ expression in the BMSC cultures. Dental pulp cells derived from erupted (P18-P21) molars display low, but detectable levels of $P P A R \gamma 2$ and FABP4 expression. The expression of PPAR 22 and FABP4 is not detected in dental pulp cells derived from unerupted (P5-7) molars. 

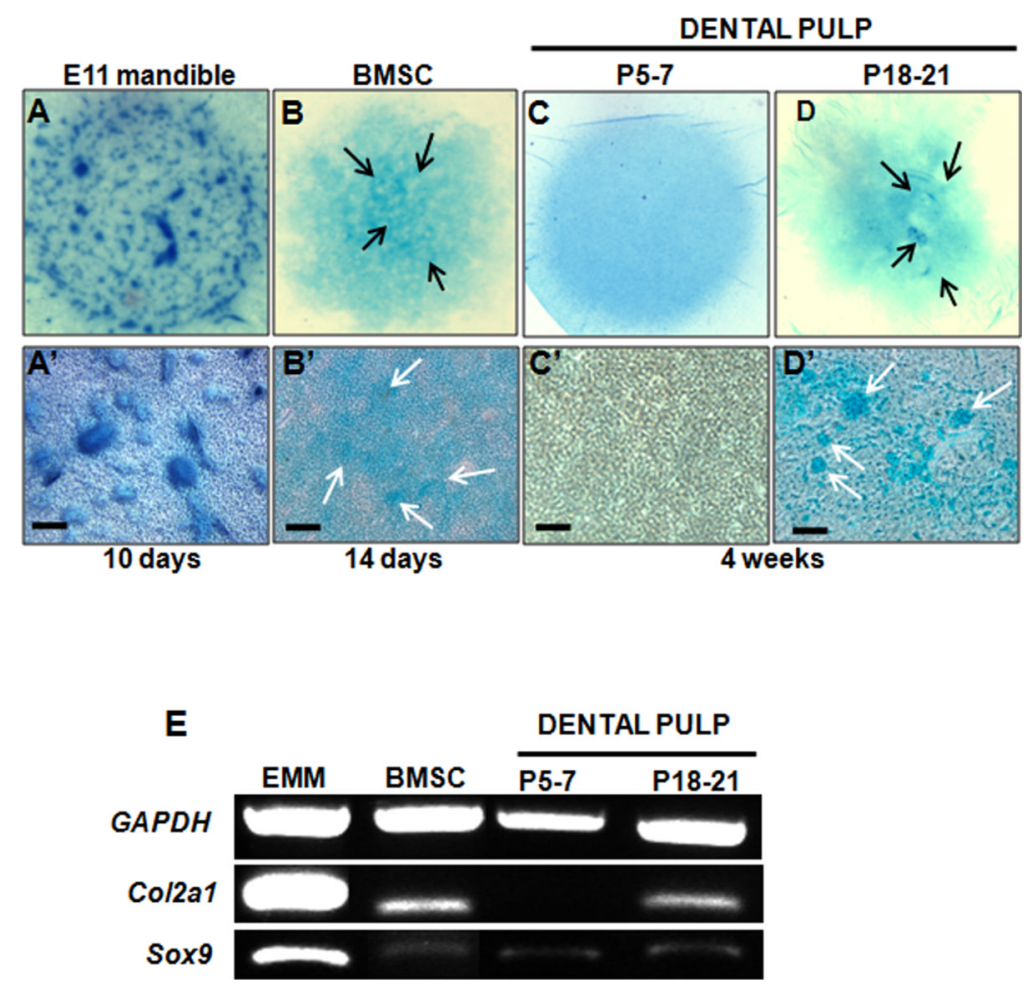

Figure 7. Chondrogenic differentiation by cultures derived from dental pulp

A-D are representative images from the whole micromass cultures stained with Alcian Blue. Micromass cultures were established from mesenchyme obtained from E11.5 mandibles (A), BMSC (B) and dental pulp obtained from unerupted (P5-7) (C) and erupted (P18-P21) (D) molars. Cultures were grown under chondrogenic condition for 10 days (A), 14 days (B) and 4 weeks (C, D). A'-D' represent bright field images of the same cultures. Micromass cultures derived from E11.5 mandibular mesenchyme display extensive chondrogenesis indicated by cartilage nodules stained with Alcian Blue (A, A'). Limited number of Alcian Blue stained nodules is detected in micromass cultures derived from BMSC (arrows in B, B') and dental pulp from erupted (P18-P21) molars (arrows in D, D'). Chondrogenesis and Alcian Blue stained nodules were not detected in micromass cultures derived from dental pulps from unerupted (P5-7) molars (C, C'). Scale bars in A'-D'= $100 \mu \mathrm{m}$.

(E) RT-PCR analysis of expression of marker of chondrogenesis in micromass cultures Note the high levels of Col2al and Sox9 expression in micromass cultures established from E11.5 mandibular mesenchyme. Levels of Col2al expression in the micromass cultures from the erupted (P18-P21) molars and BMSC are low but detectable. Also note the lack of Col2al expression in the micromass cultures from the dental pulps from unerupted (P5-7) molars. Sox9 expression was detected in low but detectable levels in all micromass cultures. 


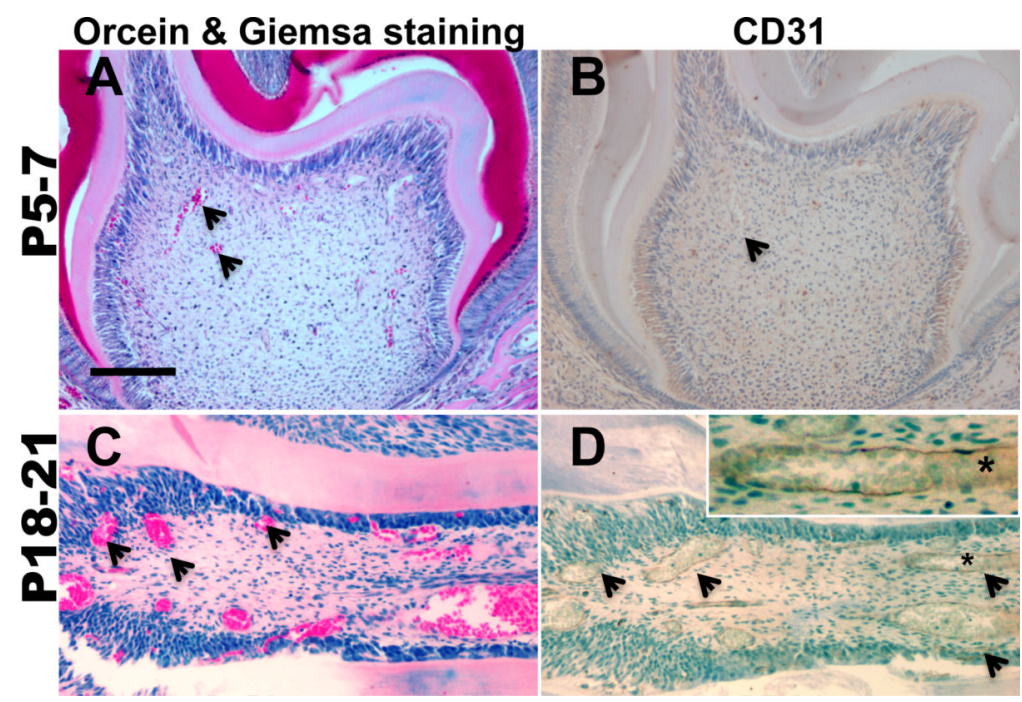

Figure 8. Vascularization in dental pulp

Cross-sections of molars from P5-7 (A, B) and P18-21 (C, D) mice processed for Orcein/ Giemsa staining $(A, C)$ and CD31 immunohistochemistry $(B, D)$ for detection of erythrocytes (stained red) and endothelial cells in the vessel walls (stained brown) respectively. Note the increases in the number of blood vessels containing red stained erythrocytes and CD31+ endothelial cells (examples indicated by arrows) in pulps from P18-21 (C) as compared to P5-7 mice. Inset in $\mathrm{C}$ represent higher magnification of a blood vessel indicated by asterisk showing CD31+ in the endothelial lining of a large blood vessel in the pulp from P18-21 mice. Scale bar $=100 \mu \mathrm{m}$ 


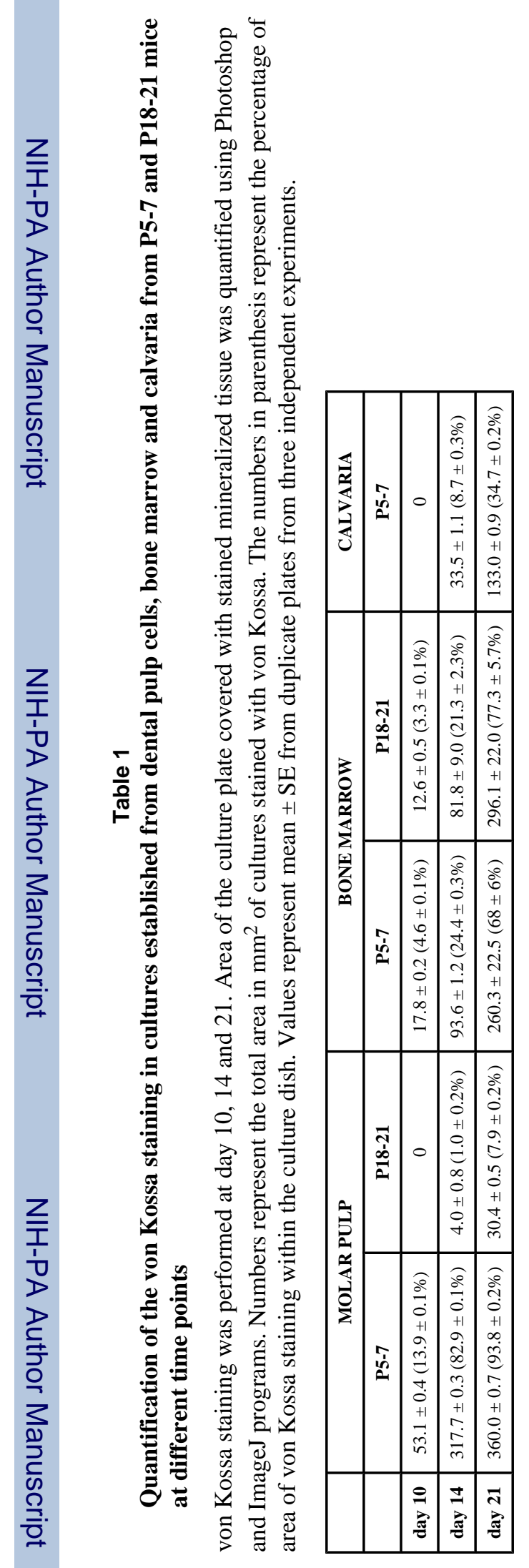

Bone. Author manuscript; available in PMC 2011 June 1. 


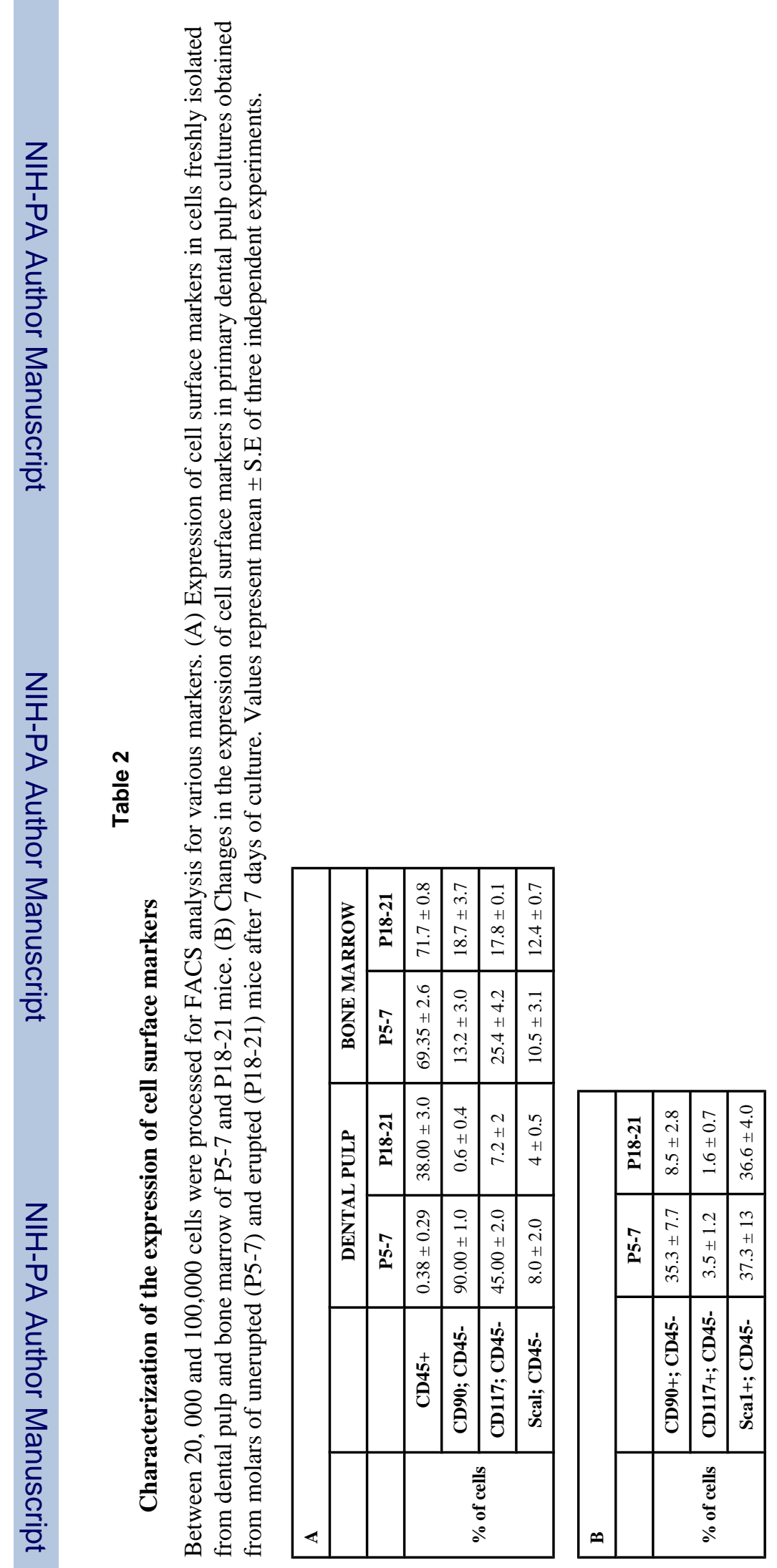

Bone. Author manuscript; available in PMC 2011 June 1. 